\title{
HPV-associated head and neck cancers in the Asia Pacific: a critical literature review \& meta-analysis
}

Running title: HPV-associated HNSCC in Asia Pacific

\section{Authors:}

Mushfiq Hassan Shaikh, School of Dentistry \& Oral Health and Cancer Research Centre, Griffith Health Institute, Griffith University, Gold Coast Campus, QLD, Australia.

Professor Nigel McMillan, School of Medical Science and Molecular Basis of Disease Research Program, Griffith Health Institute, Griffith University, Gold Coast Campus, QLD, Australia.

*Emeritus Professor Newell W Johnson, Cancer Research Centre and Population \& Social Health Research Program, Griffith Health Institute, Griffith University, Gold Coast Campus, QLD, Australia.

\section{Correspondence:}

Emeritus Professor Newell W Johnson, CMG, FMedSci

Professor of Dental Research, Building G40, Room 9.16, Gold Coast Campus, Griffith Health Institute

Parklands Drive, Southport QLD 4215, Australia.

Email address: n.johnson@griffith.edu.au, Mobile no. +61 (0) 448954344

Total number of words in manuscript:

Number of figures:

Abstract: 
Background: Malignancies of the upper aero-digestive tract are a major public health problem, especially in the Asia Pacific. Certain Human papillomaviruses (HPVs) are well-established risk factors for carcinoma of the uterine cervix and for a subset of head and neck carcinomata: however their true importance in different populations and anatomical subsites remains unclear. The major risk factors in Asia Pacific remain smoked/smokeless tobacco, areca nut, alcohol abuse and poor diet, with evidence for HPVs. We review published evidence of association of HPV with anatomical sitespecific Head \& Neck Squamous Cell Carcinoma (HNSCC) in these populations and attempt a meta-analysis.

\section{Materials and methods: From MEDLINE/PubMed/WEB-of}

SCIENCE/EMBASE/Scopus databases we found 66 relevant studies: 15 case-control studies met our inclusion criteria for meta-analysis, totaling 1146 cases \& 618 controls. HPV detection rates, sample site and size, and methods of tissue preservation and HPV detection were tabulated for each study.

Results: Studies were heterogeneous in terms of sample selection and method of detection of HPVs. Most were of limited quality. Approximately, $37.55 \%$ of overall HNSCC biopsy specimens of 66 studies reported HPV positivity of any subtype. PCR (polymerase chain reaction) was the mostly used detection method and HPV16 was the most common genotype detected. In meta-analysis, pooled prevalence of high risk types of HPV in fifteen selected studies, irrespective of anatomic site, was $40.92 \%$ (469/1146): pooled odds ratio 4.82; (95\% CI: $3.62-6.42)$.

Conclusion: In view of the significant association of HPV with HNSCC, studies with accurate subsite classification and more sensitive detection methods are necessary. Accurate data from this geographical region are essential to inform public health policies and treatment decisions, especially as studies from Europe and North America reveal HPV-driven cancers to be less aggressive, permitting treatment de-intensification.

Keywords: Head and neck cancer, human papillomavirus, Asia pacific populations, polymerase chain reaction (PCR), meta-analysis. 


\section{Introduction:}

Head and Neck Cancers (HNC) represent a biologically heterogeneous group of neoplasms involving numerous distinct anatomical sites within the head and neck. Use of the term usually excludes the skin, central nervous system, eyes, lymphatic system, and endocrine glands. Most malignancies of the head and neck arise from the mucous membranes lining [International Classification of Disease tenth revision (ICD-10)]; Lips (C00); base of the tongue (C01), oral cavity including the anterior two-third of the tongue (C02 - C06); tonsils (C09); the oropharynx (C10); nasopharynx (C11) and accessory sinuses (C12); the hypopharynx (C13), the vallecula and the larynx (C32) (1). Most malignancies in this region (approx. 85\%) specifically excluding nasopharyngeal carcinomas, which are biologically distinct are morphologically characterized as Head \& Neck Squamous Cell Carcinomas (HNSCC) and share common risk factors (2). Nasopharyngeal carcinomas are often recorded separately because they are biologically distinct, having a strong association with Epstein-Barr virus (3, 4). HNSCC is the fifth most common cancer diagnosed in the world (5). It is also one of the most common malignancies throughout Asia Pacific, including the Indian Subcontinent, accounting for $40-50 \%$ of all cancers (6). Tobacco, both smoked and unsmoked, areca nut (in these populations usually consumed as a component of betel quid) and alcohol use/abuse, often in the context of diets poor in antioxidants and minerals, are well-established major risk factors, so it is no surprise that HNSCC are most common in those countries where the consumption of tobacco, areca and/or alcohol is high (Australia, Brazil, China, France, India, Japan, Netherlands, Papua New Guinea, South Africa and Switzerland) (7). Recent studies have shown a rising incidence of Squamous Cell Carcinoma (SCC) of the oropharynx, despite the reduction of tobacco use in several of these countries (8-11). This suggests increasing prevalence of another risk factor, now clearly identified as persistent infection with so-called “high risk” types of human papillomavirus (HPV) $(12,13)$.

HPVs are a large family of viruses (the Papillomaviridae) that are small in diameter (55nm), epitheliotropic, with a genome 7200 - 8000 base pairs in length (14). Depending on their nucleotide sequences, HPVs are classified into more than 100 different genotypes, about 15 of which are regarded as "high risk" due to their oncogenic potential 
$(15,16)$, amongst which, HPV16 and HPV18, are especially closely linked with malignant transformation $(17,18)$. Approximately 25 HPV types are associated with oral lesions (17), and more than 90\% of cases of HPV-related HNSCC are associated with HPV type 16 (19, 20). Although HPV-associated HNSCC is well documented in the western world including Australia, studies on South Asia, South East Asia and East Asia are few and inconsistent. We present here a critical review of published studies. Clearly, further work on large case series with well-defined anatomical subsites and utilizing the sensitive and specific methods available is required.

\section{Epidemiology \& Risk Factors:}

HNC is a serious problem in much of the world. The burden is approximately 599,637 new cases per annum worldwide: 300,373 for lip plus oral cavity; 156,877 for larynx; 142,387 for other pharynx (oro- \& hypo-pharynx) excluding the nasopharynx (International Agency for Research on Cancer, Globocan 2012, http://globocan.iarc.fr/Pages/fact_sheets_population.aspx, accessed on 21 July, 2014) (21). While there is considerable geographical variation, the major burden is in developing countries. This includes South Asia where the annual incidence is 194,742 new cases and mortality 136,199 p.a. (an age-standardized rate of approximately 20.70 per 100,000 persons p.a.), South East Asia with 35,228 incidence rate and East Asia with the incidence of 79,477 per annum (International Agency for Research on Cancer, Globocan 2012, http://globocan.iarc.fr/Pages/fact_sheets_population.aspx, accessed on 21 July, 2014), and this is largely because of extensive use of tobacco and areca nut, poverty and poor oral health (21). The overall incidence of HNSCC in the Asia Pacific is 314,778 new cases per year, which is more than half of the total HNSCC cases worldwide. The mortality rate is also very high, approximately 199,537 p.a.

Although HPV-associated cancers are best described in cancer of the uterine cervix, where $>99 \%$ of cases harbor HPV (22), a significant association of HPV with HNSCC has shown an overall worldwide proportion of 25-35 \%, but with substantial variability (23-25). Since the association of HPV with HNSCC was first reported in the mid 1980s, 
rising rates of oropharyngeal cancer (C01, C09, C10 \& C12) especially of the tonsil (C09) and base of the tongue (C01) have been shown in Europe and in the USA, (26-29). In the USA, between 1984 and 2004, the incidence rates of HPV-associated oropharyngeal cancer (C01, C09, C10 \& C12) increased from 0.8/100,000 to 2.6/100,000 person - year (from 16.3\% to 71.7\%) (27). In Sweden and Finland the incidence of HPVassociated tonsil (C09) carcinoma rose by 3-fold during 1970 (29\%) to 2007 (93\%) and by 2-fold between 1956 and 2000, respectively (30,31). This specific subsite of oropharyngeal cancer (tonsil carcinoma) has also shown 3-fold increase in England between 1995 and 2010 (32). Significant trends have been described in Australia, where HPV-related oropharyngeal cancer (C01, C09, C10 \& C12) increased from 20.2\% (19871995) to 63.5\% (2006-2010) (33). A recent meta-analysis of contemporary studies on HPV-associated oropharyngeal cancer (C01, C09, C10 \& C12) estimates approximately 69.7\% prevalence in North America and 73.1\% in Europe (34). Unfortunately, such studies from Asia Pacific region have been reported show-striking differences. Reports only from India have given prevalence rates of the association of HPV with oropharyngeal cancer (C01, C09, C10 \& C12) approximately 27.28 \% (22.85 - 31.71\%) (35, 36).

Head and neck cancer sites with high prevalence have a distinctly different structure, and encompass the lymphoid mucosae of Waldeyer's ring $(31,37)$. This area of the oropharynx is an embryonic transformation zone, and most HPV-positive oropharyngeal cancers (C01, C09, C10 \& C12) arise from this (20). It is lined by non-keratinized stratified squamous epithelium, the crypts of which contain basal keratinocytes, which function as traps for antigens and are susceptible to nuclear integration of HPV DNA (20, 31). Histologically, HPV-positive HNSCCs exhibit poorly differentiated, non-keratinized basaloid morphology (38-40).

In the western world, patients with HPV-related HNSCC are generally Caucasian, are younger, male, have a comparatively high socio-economic status, are non-smokers and non- or light drinkers $(8,41-46)$. There are important associations with sexual behavior, especially sexual debut at early age and a high number of lifetime vaginal and especially oral sex partners, these contributing to a 2 to 5 fold increase in the incidence rate $(8,47$ - 
55). Although it seems that HPV-positive HNSCC is more likely to develop in Caucasians (including Australians), a significant prevalence has also been noted in the Asia Pacific populations (except Oceania), perhaps associated with changing sexual mores and the infiltration of western culture (53).

\section{Molecular Pathogenesis of HPV-associated HNSCC:}

It is widely accepted that HPV16 and HPV18 are responsible for approximately $70 \%$ of cancers of the uterine cervix (56) and are strongly associated with anal, vulvar, and penile cancers $(20,57,58)$. However the exact biological mechanisms are not completely understood. The process is thought to commence with integration of HPV DNA into the host keratinocyte genome. Two of the early genes, E6 and E7, are thought to be responsible for malignant transformation (Figure 1). Suppression of the transcriptional repressor gene $E 2$ of HPV allows continuous expression of $E 6$ and $E 7$, which then function as oncogenes throughout the life of what become malignant keratinocytes (59). The E6 oncoprotein localized in the nuclear matrix targets and degrades the product of the cell's p53 tumor suppressor gene, thus inhibiting p53-dependent cell cycle arrest \& induced apoptosis $(60,61)$. E6 oncoprotein also enhances telomerase activity, favoring immortalization of affected keratinocytes. In addition, viral E7 promotes cellular proliferation by down-regulating the cyclin-dependent kinase (CDK) inhibitors p21 \& p27, and by inactivating Rb (retinoblastoma) protein $(62,63)$ by binding with its hypophosphorylated forms (pRb, p130, p107) (64-66). Thus, loss of both p53 and Rb function ultimately leads to malignancy.

HPV-positive and HPV-negative HNSCC are distinctly different diseases. Understanding their molecular mechanisms is essential for effective bio-prevention and individualized biotherapies.

\section{Materials and Methods:}

Search Strategy: WEB of SCIENCE (Thompson Reuter, NY, USA), EMBASE, SciVerse Scopus (Reed Elsevier PLC, Amsterdam, Netherlands), MEDLINE and PubMed (US National Library of Medicine, MD, USA) were used to conduct a comprehensive literature search on HPV-related Head and Neck Cancer in the Asia 
Pacific. The search was limited to English language and published studies from 1980 to May 2014. Both MeSH (Medical subject Headings) and more general search terms were used. MeSH terms were 'cancer', 'neoplasm', ‘squamous cell carcinoma', 'oral cancer' and numerous permutations of 'Head and Neck Cancer (HNC)' and its subsites ('oral cavity’, ‘oropharynx’, ‘nasopharynx’, 'larynx’, ‘tonsils’, ‘tongue’) associating with 'Human Papilloma Virus (HPV)’ and ‘South Asia’, 'South-East Asia’, 'East Asia’, 'Oceania’ and individual countries ('India’, ‘Bangladesh’, 'Pakistan’, 'Sri-Lanka’, 'Nepal’, ‘Bhutan’, ‘Maldives’, ‘Afghanistan’, ‘Malaysia’, ‘Indonesia’, ‘Thailand’, 'Vietnam', ‘Cambodia’, ‘Philippines’, ‘China’, ‘Japan’, ‘Taiwan’, ‘Hong Kong’, ‘South Korea’, ‘North Korea’, ‘Australia’, ‘New Zealand’ and 'Papua New Guinea’ ). A secondary search was also performed on the references cited in the selected articles.

Study Selection and Data Extraction: Data extraction was performed by all three authors, focusing on: country of origin, demographics of participants, number of cancer cases, proportion of HPV positive cancers in relation to all carcinomas at HNC sub sites, HPV detection methods, and HPV genotypes. Based on the CONSORT statement 2010 (Consolidated Standards Of Reporting Trials), Asia Pacific data were retrieved by reading the abstracts. In order to explore the possibility of a meta-analysis, we applied the additional criterion of case: control study design. PRISMA 2009 (Preferred Reporting Items for Systematic reviews and Meta-Analysis) guidelines were followed while selecting studies for meta-analysis (Figure 1).

Statistical Analysis: STATA v.12 (Stata Corp LP, College Station, Texas, USA) software was used. Firstly, to evaluate any significant difference, two-sided 95\% confidence intervals (95\% CI) were calculated by the 'Wilson Score' method in all 66 selected studies (Tables 2 and 3). For meta-analysis, dichotomous data of the numbers of HPV-positive and -negative head and neck cancers were analyzed by Forest plot. Then the odds ratios (OR) and 95\% confidence intervals (CI) were calculated by the 'Wilson Score' method (67) for individual studies. The overall proportions were examined by meta-analysis to estimate the pooled prevalence of HPV in non-site specific HNSCC using the Mantel-Haenszel method. The Cochrane Chi-squared or I-squared statistic $\left(\mathrm{I}^{2}\right)$ based Q statistic and a random effects model (REM) with the DerSimonian-Laird method 
were used to assess the variation between study results $(68,69)$. Potential publication bias was assessed using funnel plots (70).

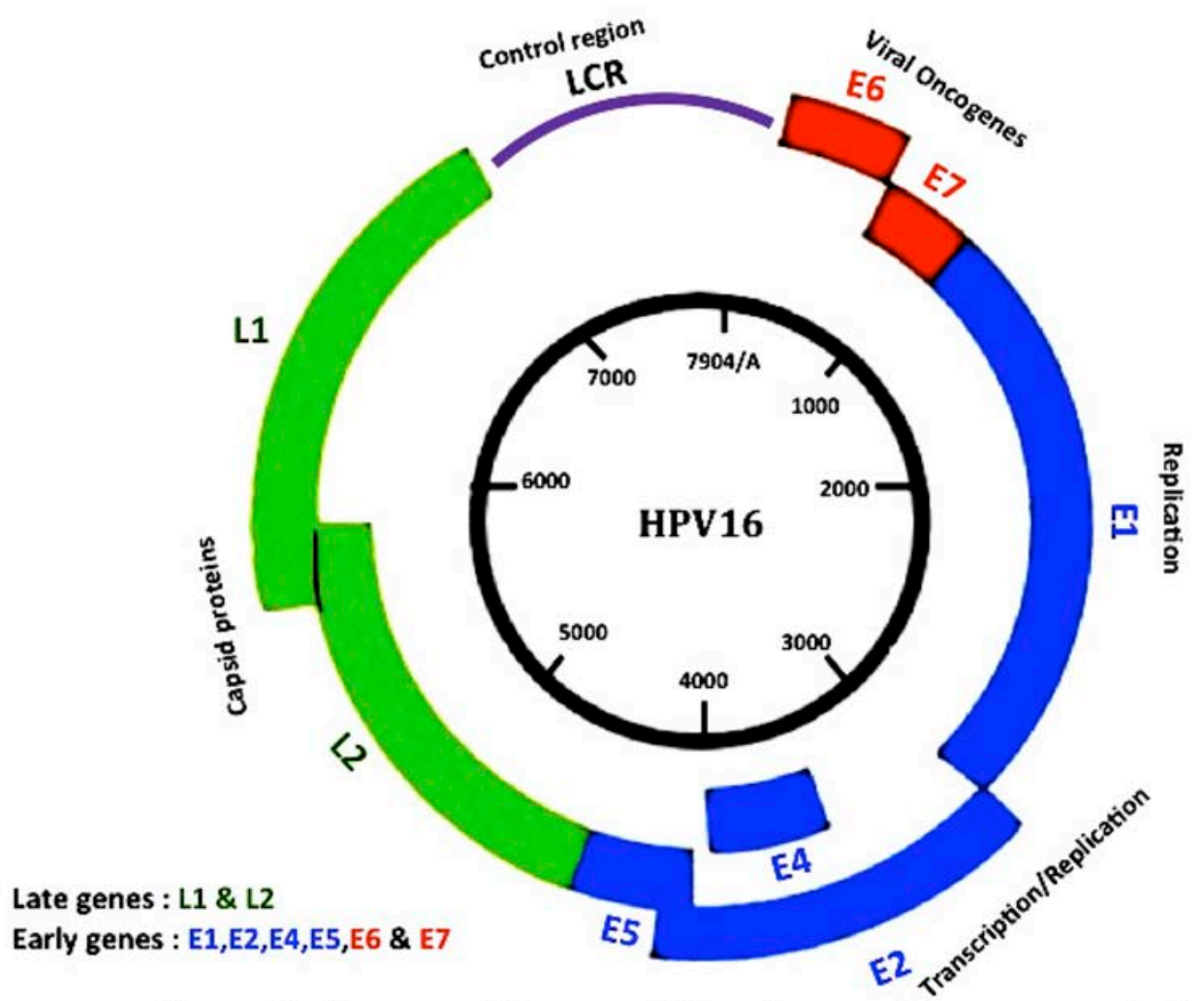

Figure - 1: A cartoon of Human papillomavirus type 16 genome organization. 


\section{PRISMA Flow Diagram}

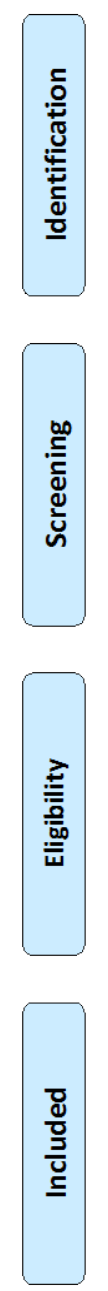

Records identified through WEB of SCIENCE, EMBASE, SciVerse Scopus, MEDLINE, PubMed database searching $(n=65$ )

Additional records identified through other sources $(n=2)$
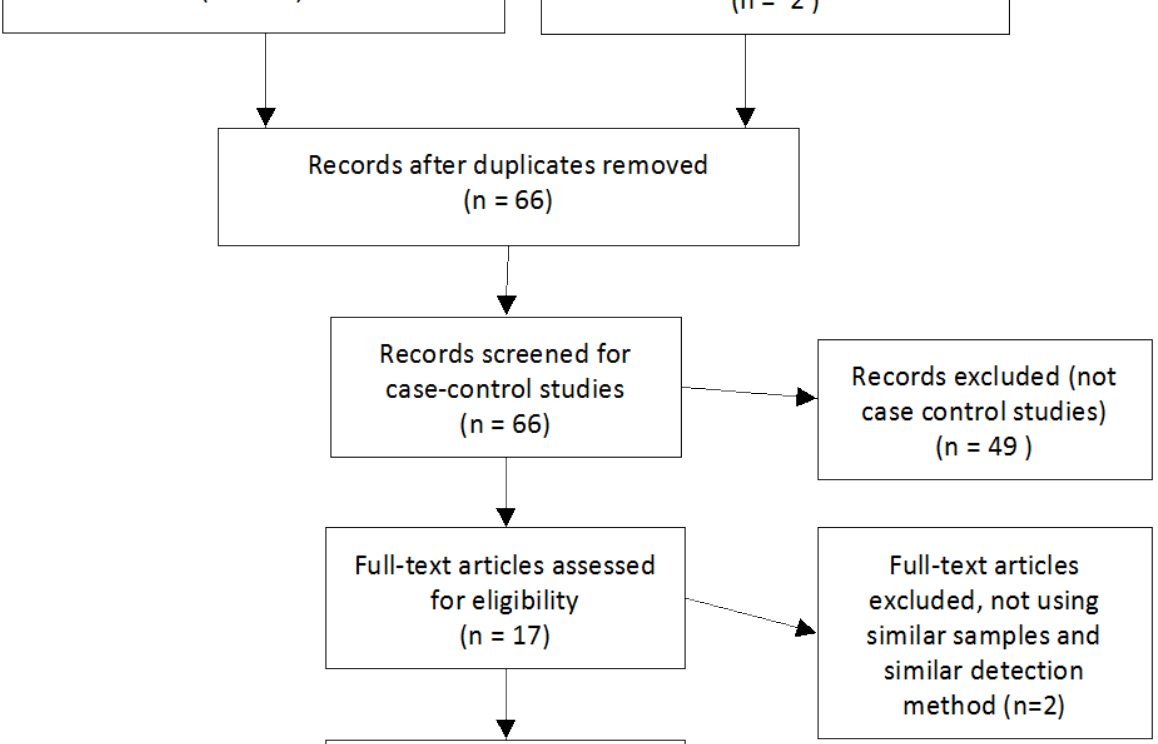

Studies included in qualitative synthesis $(n=15)$

Studies included in quantitative synthesis (meta-analysis) $(n=15)$

Figure 2 : PRISMA flowchart of the selection process of studies on HPV- associated head and neck cancer form South Asia. 


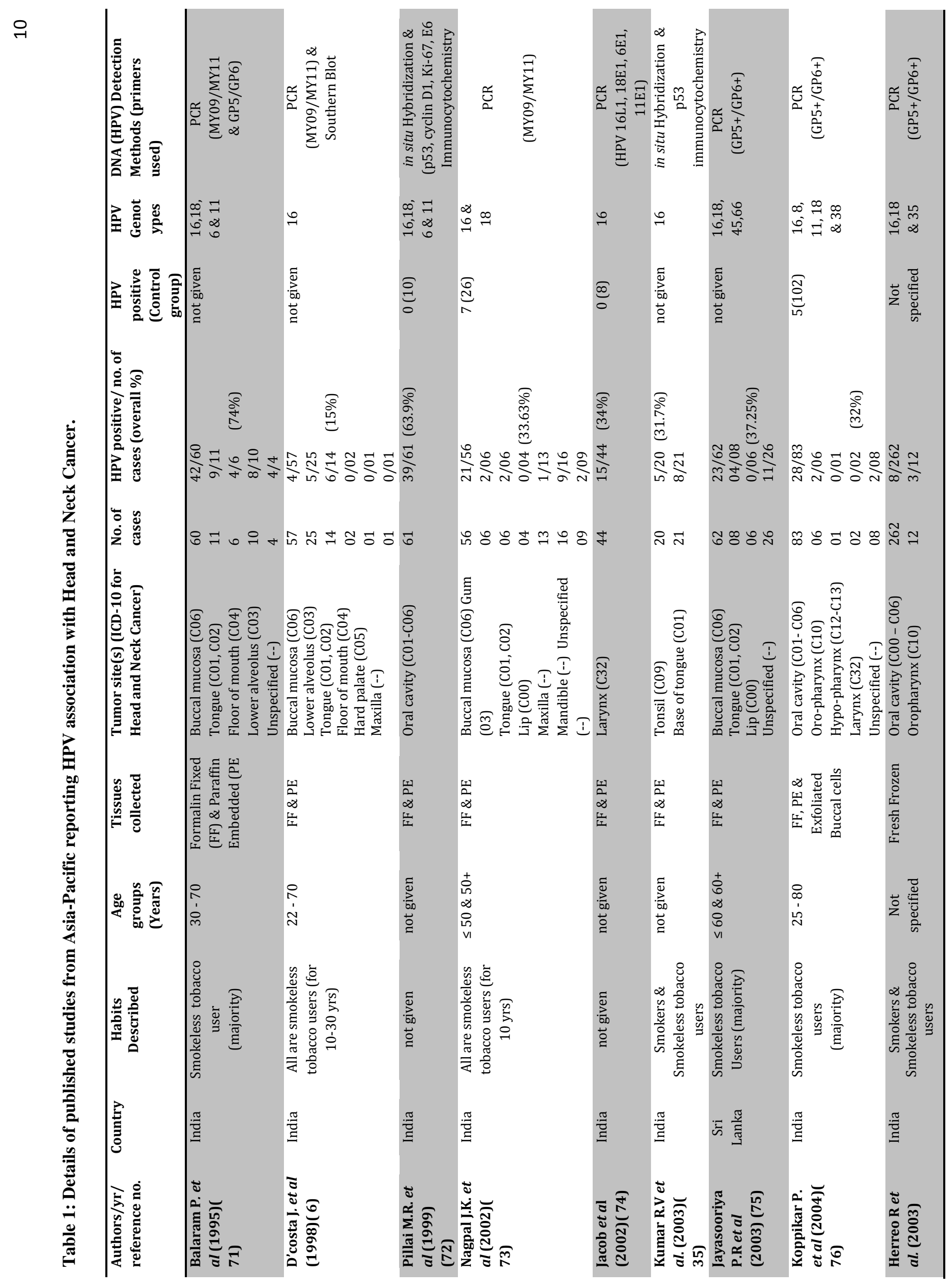


7

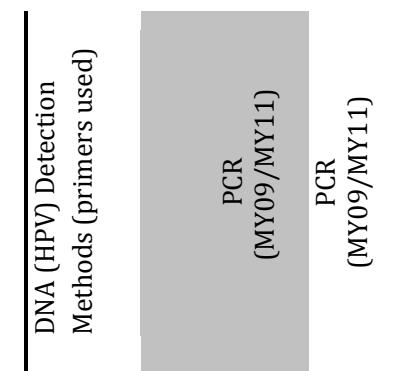

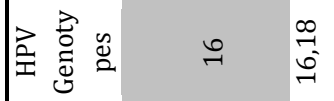

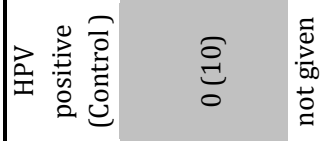

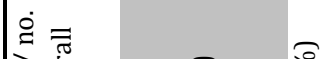

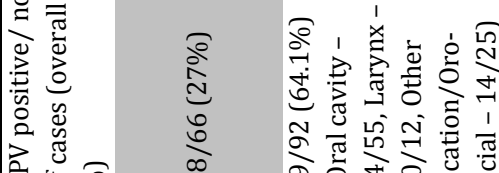

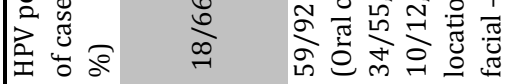

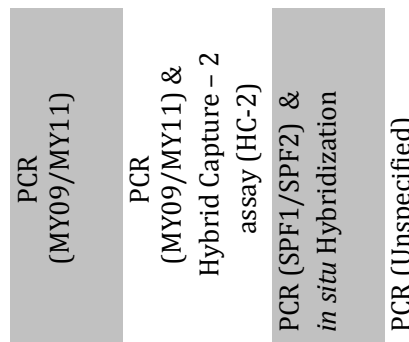

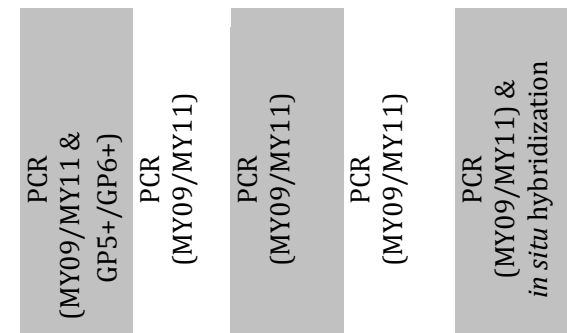

要

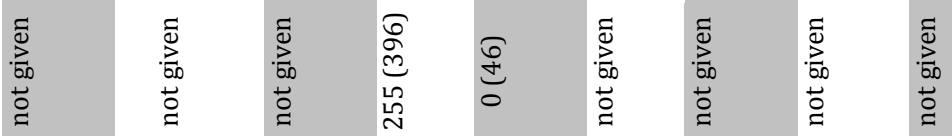

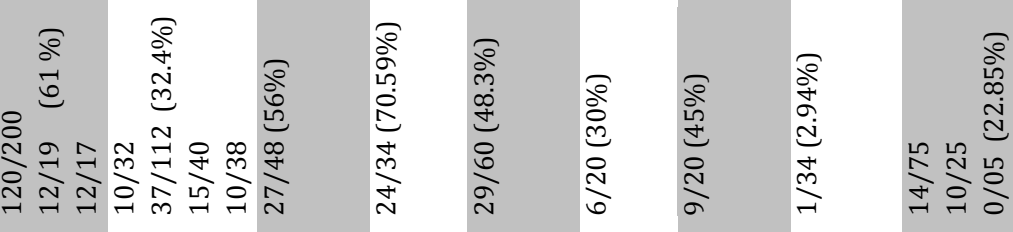

产

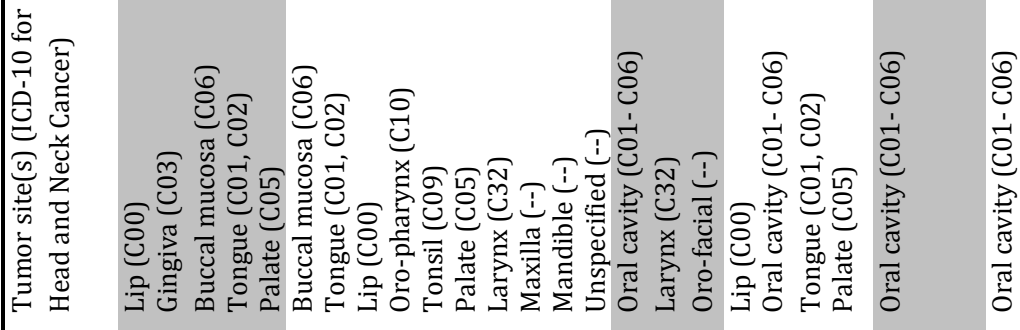

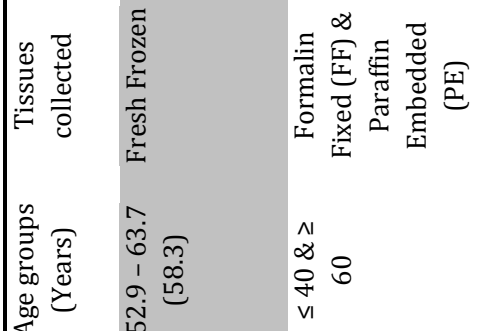

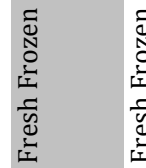

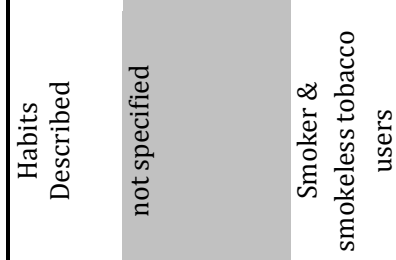

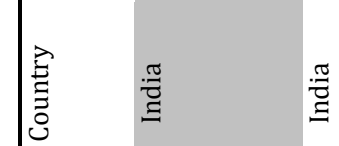

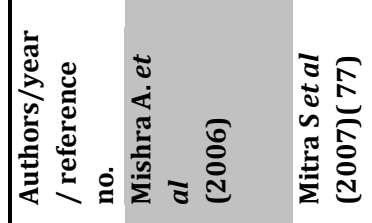

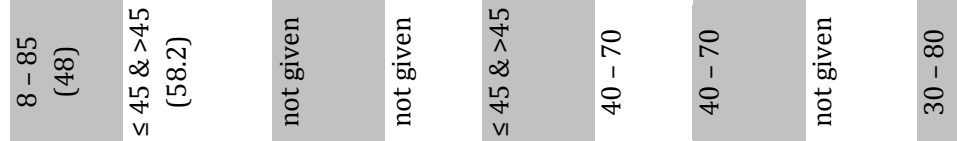

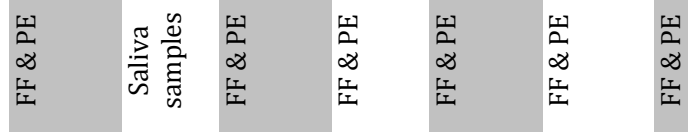

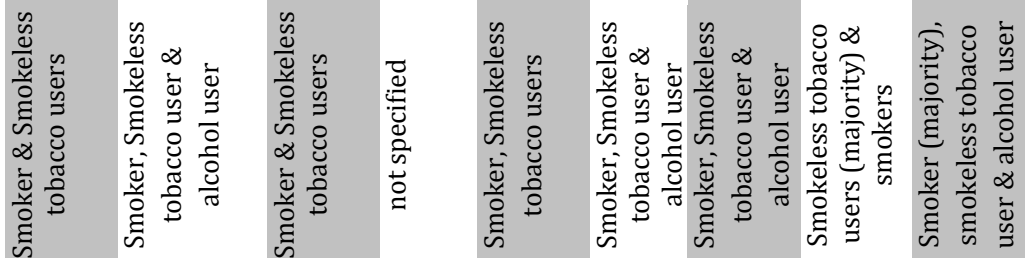

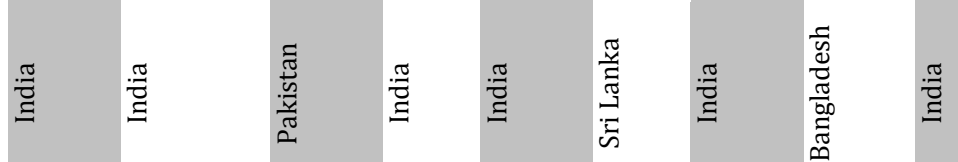

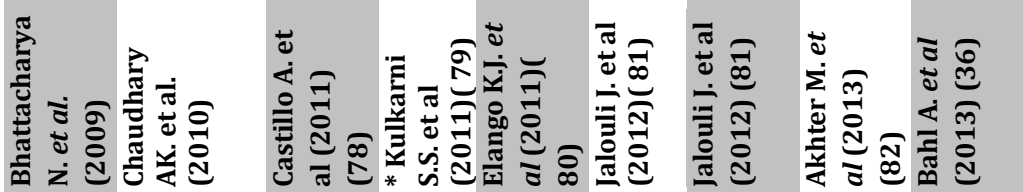




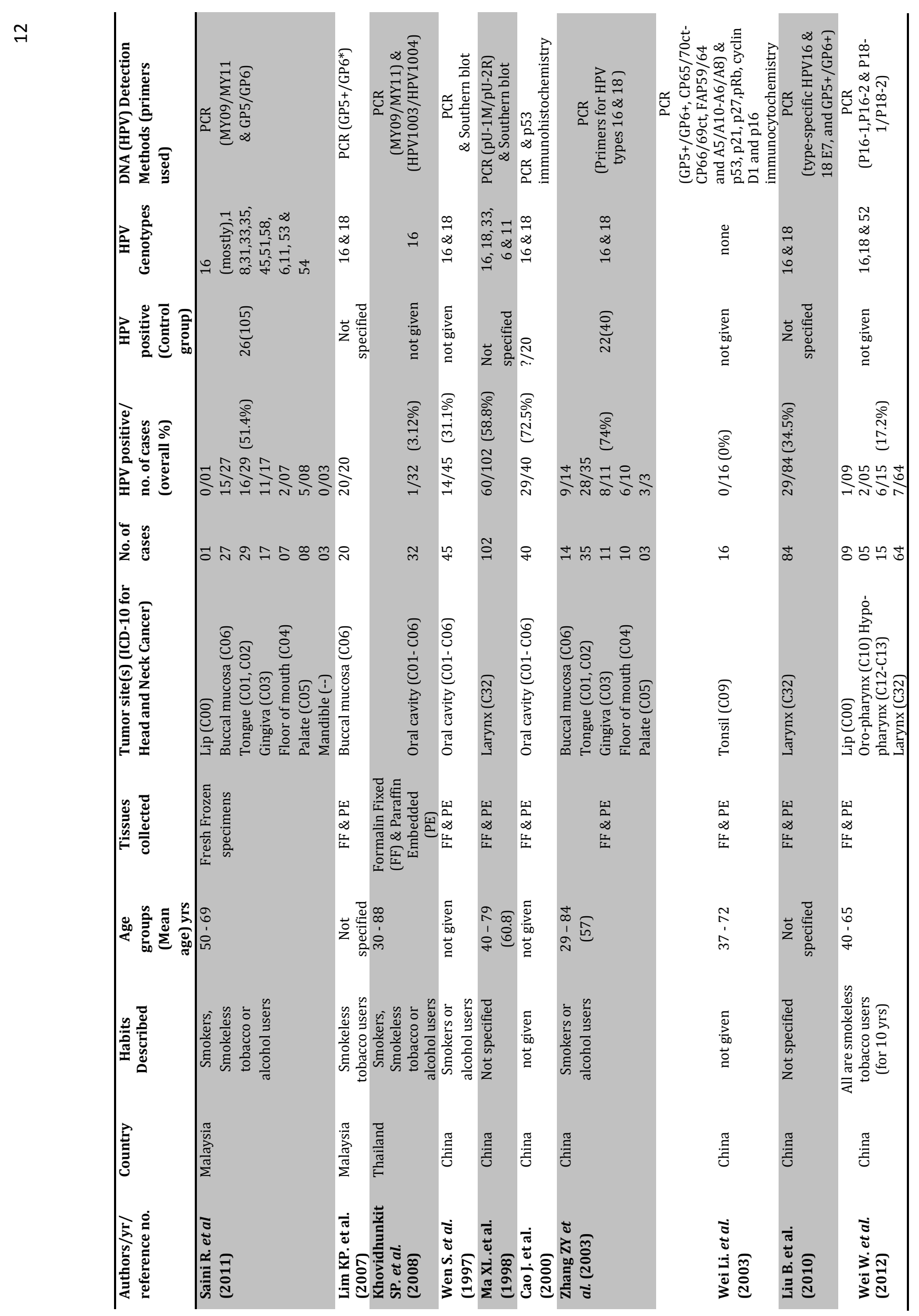




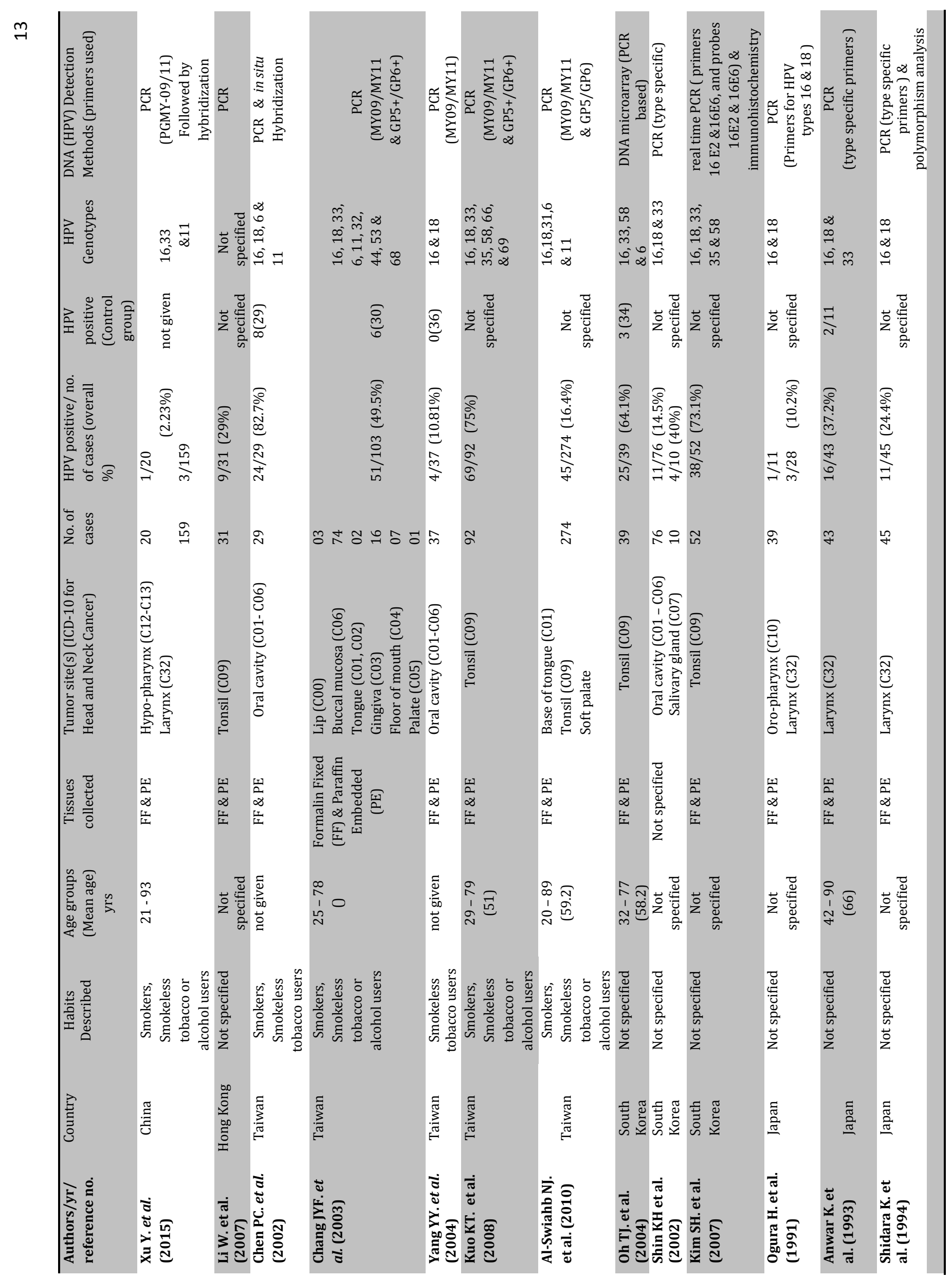




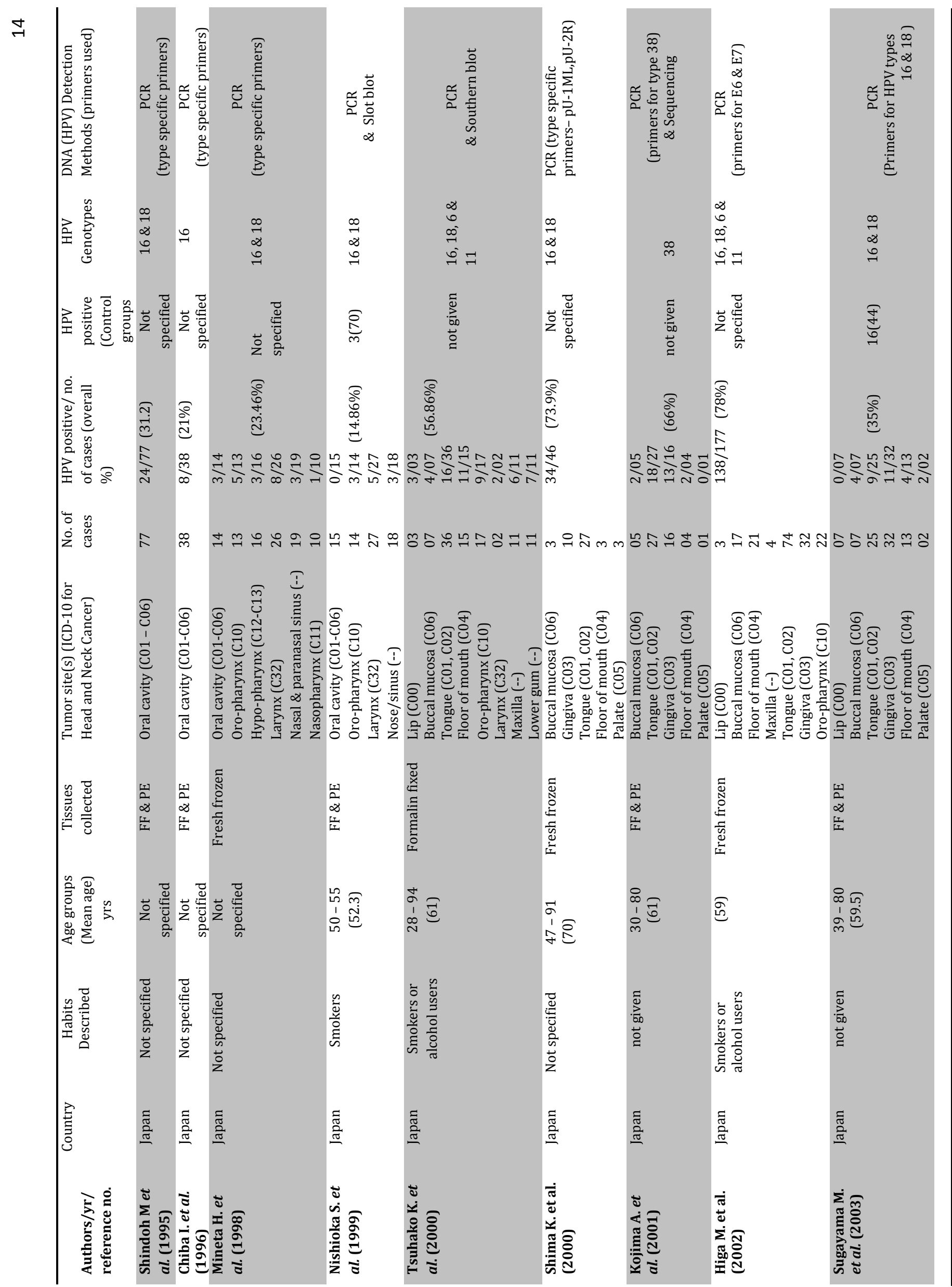




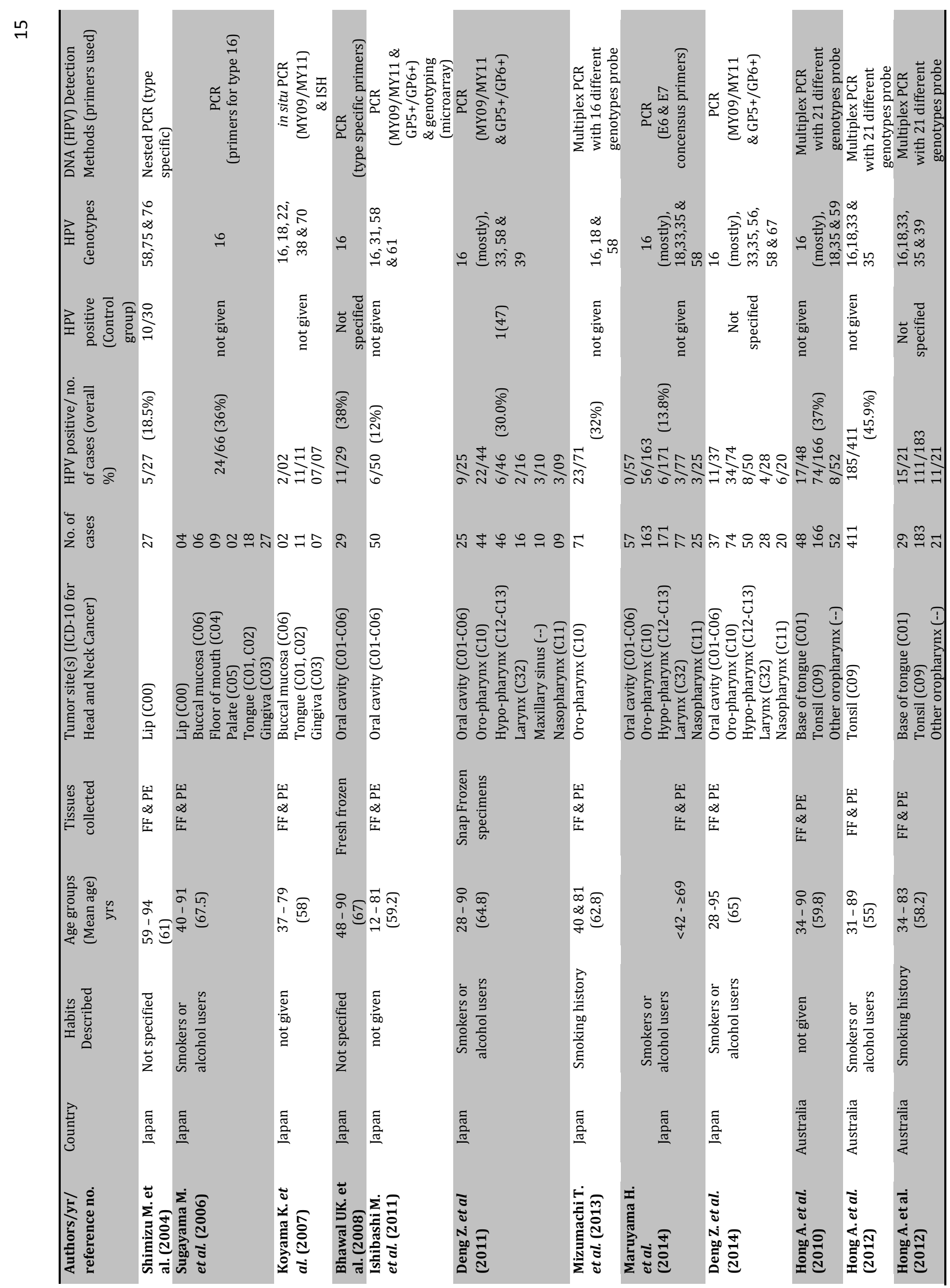




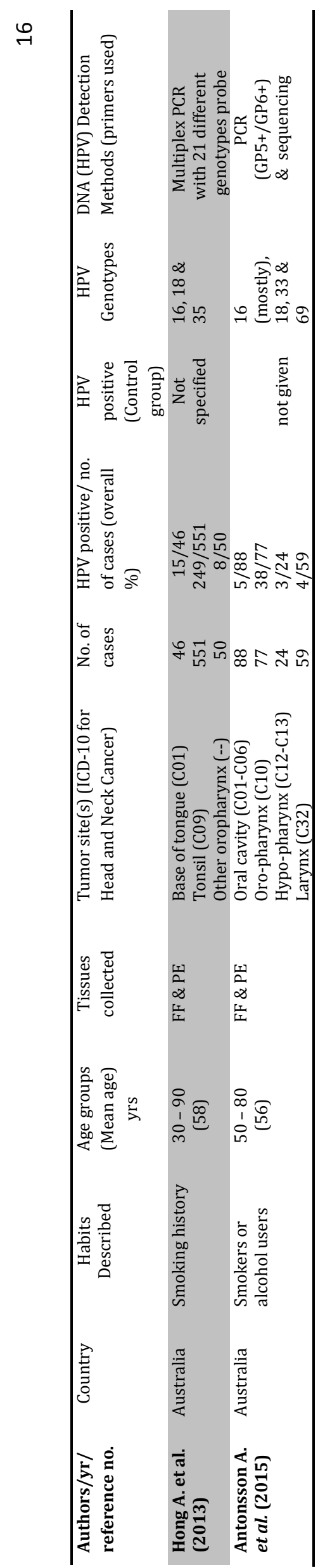




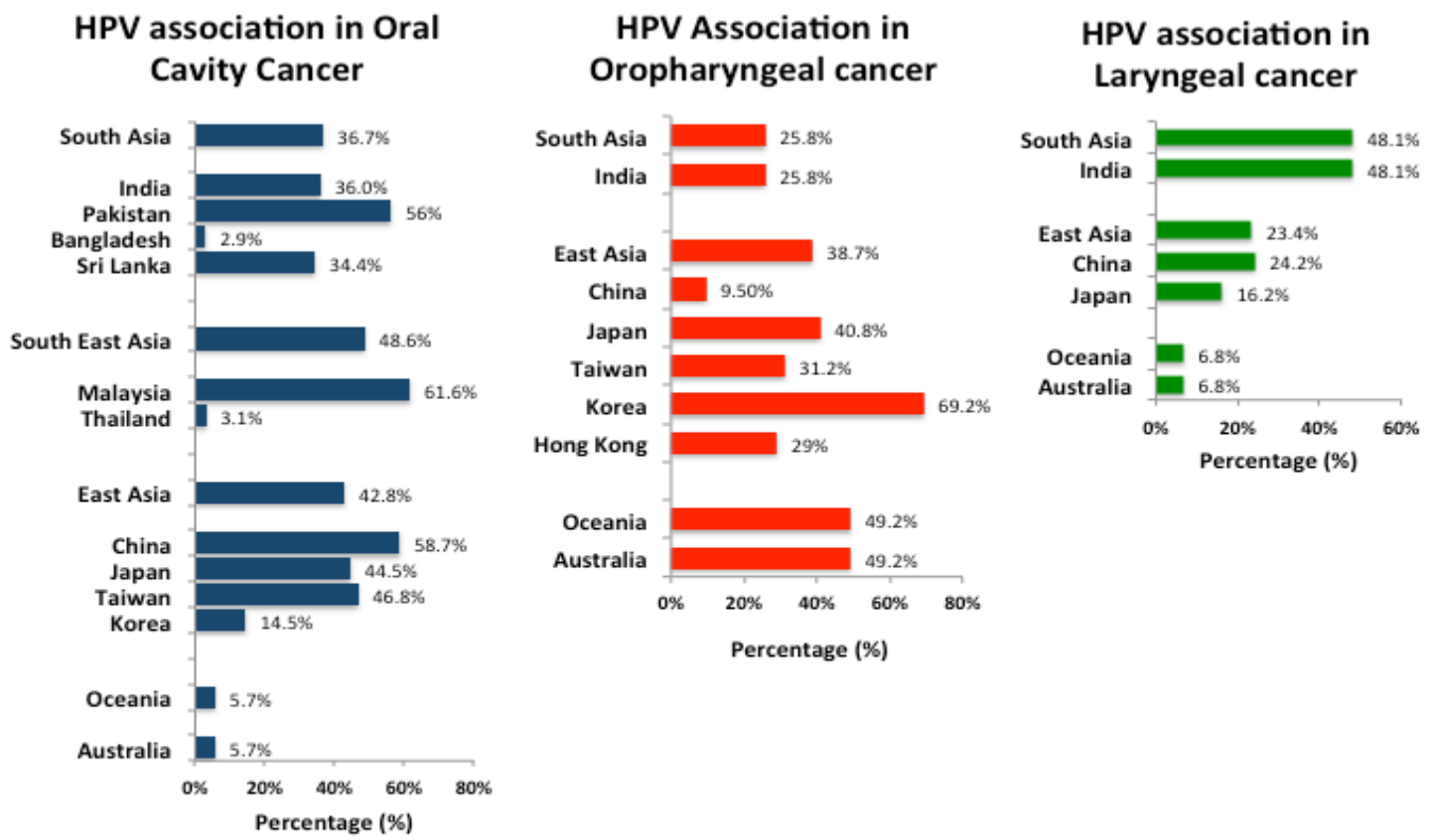

Figure 2 : Prevalence of HPV in head and neck squamous cell carcinoma by anatomical sites and countries of Asia Pacific.

Table 2: Studies of Head and neck cancer in the Asia-pacific by major cancer sites and overall HPV prevalence:

\begin{tabular}{lllll}
\hline Site & Geographic Location & $\begin{array}{l}\text { Number } \\
\text { of studies }\end{array}$ & $\begin{array}{l}\text { Number of } \\
\text { cases }\end{array}$ & $\begin{array}{l}\text { Overall HPV } \\
\text { prevalence (95\% Cl ) }\end{array}$ \\
\hline Oral cavity & $\begin{array}{l}\text { South Asia, South East } \\
\text { Asia, East Asia \& Oceania }\end{array}$ & 43 & 3081 & $38.91(37.21-40.61)$ \\
\hline Oropharynx & $\begin{array}{l}\text { South Asia, East Asia \& } \\
\text { Oceania }\end{array}$ & 22 & 2806 & $44.29(25.29-63.29)$ \\
\hline Larynx & $\begin{array}{l}\text { South Asia, East Asia \& } \\
\text { Oceania }\end{array}$ & 17 & 838 & $24.46(22.99-25.93)$ \\
\hline Overall & & & 6725 & $39.36(38.38-40.43)$ \\
\hline
\end{tabular}




\section{Results:}

From all the mentioned electronic data bases, we identified 67 studies that have reported prevalence of one or more HPV types, patients' demography, methods of tissue preservation, HPV detection methods, and provided information about anatomical subsites in Asia Pacific region. Details of all 67 studies are tabulated in Table 1. A total of 7288 cases from different countries of Asia- Pacific region include 3081 cases from Oral cavity (C00 - C06), 2806 cases from oropharynx (C10), 980 cases from the larynx (C32) and 322 cases from hypopharynx, the remaining 99 cases being from unspecified subsites of head and neck region. Fifty of these 67 studies were cross sectional and 17 were case control. Many did not have a control or comparison population. Only 17 studies were of case-control design. However, 16 of these 17 studies used tissue samples, one used saliva (). Tissues were either fresh-frozen or paraffin-embedded. Among those using tissue, 15 used PCR as HPV DNA detection method, the other in situ hybridization. Ultimately, fifteen case- control studies met our inclusion criteria for meta-analysis.

Approximately, $37.55 \%$ (95\% CI, 36.46 - 38.64) of total HNSCC specimens showed HPV positivity of any subtypes in Asia Pacific region. By cancer site, the overall pooled HPV DNA prevalence estimates 38.91\% for Oral cavity (C00, C02 - C06), 44.29\% for Oro-pharynx (C10, C09 \& C11), 9.9\% for hypopharynx (C12) and 27.04\% for laryngeal cancer (C32). Our data analysis by anatomical site and geographical location shows the highest HPV prevalence in Oral cavity squamous cell carcinoma in South East Asia (48.61\%), followed by East Asia (42.84 \%), 36.66\% in South Asia and lowest in Oceania (5.6\%). In oropharyngeal cancer, HPV prevalence is significantly higher in Oceania (49.32\%) compared to East Asia (38.70\%). The lowest HPV prevalence in oropharyngeal cancer was noted in South Asia (25.74\%). However, this region (South Asia) showed the highest HPV prevalence in laryngeal cancer (48.05\%), where as the lowest HPV prevalence was detected in Oceania (6\%). No data on HPV-associated oropharyngeal or even laryngeal cancer was available from South East Asia. Considerable heterogeneity was present between and within regions and countries (Fig-2).

HPV16 was the most common type detected in all the HPV DNA positive cases from Asia Pacific, accounted for $90 \%$. Although it was found to be the most prevalent type, the 
prevalence varied between sites and regions. HPV16 prevalence was higher in oropharyngeal cancer $75 \%$ compared to oral cavity cancer $70 \%$ and laryngeal cancer $67 \%$. HPV18 was the second most common oncogenic type detected in this region. Other oncogenic HPV types were detected in at least one of all specimens; HPV31, 33, 35, 39, 45, 51, 52, 53, 58, 66, 68 \& 70. In addition, some low risk and non-oncogenic types were also detected, including HPV6, 11, 38, 44, 54, 61, 69 and 22. Multiple HPV infections were rarely detected $15 \%$ and in most instances they were co-infected with HPV16.

The average age group of the patients was 57.3 years. In East Asia the patients' average age is slightly higher (60.8) compared to South East Asia (59 years), Oceania (56.9 years) and South Asia (52.53 years). Although most studies presented information about HPV prevalence stratified by sex, not much significant differences were notified between men and women. However, male predilection has been noted. Majority of the study populations were presented with stage III and stage IV disease and cases of moderately differentiated squamous cell carcinoma showed higher HPV infectivity as compared to well-differentiated or poorly differentiated cancer (ref.). All except 3 studies used PCR as HPV DNA detection method, two of these three, used ISH and the other used DNA microarray.

Meta-analysis of fifteen non-site specific case-control studies computed to an HPV prevalence of $40.92 \%$ (469/1146; summary OR: 4.82; 95\% CI: 3.62 - 6.42) (Figure 3). The overall odds ratio indicated that the risk for HPV-association was approximately 5 times more in HNSCC patients compared to non-cancerous control group in the Asia Pacific. Considerable heterogeneity was present across these studies $\left(I^{2}=68.8 \%\right)$. Metaanalysis stratified by anatomical site reported that HPV-association in more stronger for oropharyngeal cancer (OR: 14.66; 95\%CI: 6.09 - 35.26), less stronger for oral cavity cancer (OR: 4.06; 95\%CI: 3.05 - 5.39) and laryngeal cancer (OR: 3.23; 95\%CI: 1.37 7.61). Although there was evidence of heterogeneity between in these effects for oral cavity cancer $\left(\mathrm{I}^{2}=68.8 \%, p=0.000\right)$, but no heterogeneity was noted for laryngeal cancer $\left(\mathrm{I}^{2}=0 \%, p=0.553\right)$ and oropharyngeal cancer $\left(\mathrm{I}^{2}=0 \%, p=0.644\right)$. However, it should be noted that the study effect size and number of samples were small in both oropharyngeal cancer and laryngeal cancer studies. 


\section{Discussion:}

Since tobacco and areca nut/betel quid-related HNSCC has long been the major concern, few studies have been conducted on the Asia Pacific populations to determine HPV associations, especially in oropharyngeal cancer (except Australia). This review of studies from the Asia Pacific assessed the association between HPV and head and neck cancer in specific sites. The overall pooled prevalence in our selected 66 studies from the Asia Pacific region was (37.55\%) concordant with the recent meta-analysis by Termine et al. but slightly higher than the other meta-analysis by Ndiaye et al., those indicated a worldwide prevalence of 34.5\% (95\% CI; 28.4 - 40.6) and 29.5\% (95\% CI; 25.5 - 33.6) respectively (83). However, our analysis suggested a higher prevalence of HPV in oropharyngeal cancer (OPC) (44.29\%; 95\% CI, 25.29 - 63.29), compared to oral cavity cancer (OCC) (38.91\%; 95\%CI, 37.21 - 40.61) and laryngeal cancer (24.46 \%; 95\%CI, 22.99 - 25.93) in the Asia Pacific (Tables 2).

Although the prevalence of HPV-associated oropharyngeal cancer from our study on Asia Pacific shows similarity to the worldwide prevalence documented by Ndiaye et al (45.8\%), the estimated association is much higher in Europe (73\%) and in the North America (70\%)(ref.). Significant heterogeneity of HPV-associated OPC was noted when analyzed by separate geographical locations of Asia Pacific region indicating 25.8\%, 38.7\% \& 49.2\% in South Asia, East Asia and Oceania respectively. The HPV-associated OCC prevalence noted to be higher in the Asia Pacific (38.91\%) compared to other parts of the world; Europe (17.5\%), North America (13.4\%) and South America (33.1\%) (). However, the prevalence becomes much higher if we exclude Oceania from the Asia Pacific (42.88\%). Our findings on HPV-associated OCC prevalence support previous reviews from Kreimer et al. and Ndiaye et al. where it was reported to be higher in Asian populations; 33\% and 43.4\% respectively (25). Estimates for an association with cancer of the larynx are much lower, averaging 25\% in the Asia Pacific; with a wide range of $6 \%$ to $48.05 \%$. However, similar variability has been suggested from other parts of the world, ranging from 9.4-27\% in the USA, 4.4-52\% in Europe and 32-37.3\% in South America (37, 84-94). These differences could be explained by issues regarding number of 
cases added in the study, types of collected specimens, methods of tissue preservation, techniques used for DNA detection, geographical location or habitual distribution.

Our meta-analysis was based only on 15 case-control studies, these being from Asia Pacific on non-site specific HPV-associated HNC, and this is clearly a limited database to generalise from. However, site-specific stratified meta-analysis indicated stronger HPV association with oropharyngeal cancer compared to oral cavity, laryngeal and non-site specific Head and neck cancers in this particular region. Such finding supports the fact about the oropharyngeal cancer is commonly associated with HPV even in the Asia Pacific.

Although the demography of HPV-associated HNC patients around the world emphasize young adult males with no/limited history of smoking or drinking, the majority of the cases from the Asia Pacific reviewed here indicate habitual use of tobacco in smoked or smokeless forms and alcohol use/abuse. A high incidence of HPV infection has also been noted in betel quid and tobacco chewers $(6,71,73,76)$. In both sexes, the incidence of HPV-associated HNC showed no significant difference in the Asia Pacific populations. Although two studies from India have shown a male predominance with male \& female ratio reporting 11:1 and 7:1, however, both of these studies have issues with small sized study groups and unequal sex distribution in sample selection process $(36,77)$. Majority of HPV-associated HNC patients from the South Asia, South East Asia and East Asia are relatively younger with lower socio-economic background. The median age of patients from the Asia Pacific estimates 57 years, relatively lower, compared to HPV-related HNSCC patients of Europe (50-59 and 60+ years) and the USA (57 - 63 years) (8, 95, 96). In addition, none of these studies from The Asia Pacific have illustrated about the sexual behavior of the HPV positive patients. Only one recent extensive study from north India has shown a strong association of higher number of lifetime sexual partners and high-risk sexual behaviors (oral and anal sex) with HPV positive oropharyngeal cancer group as compared to patients who are HPV negative (58\% vs. 21\%) (36). Another study from Australia shows a significant association of HPV with the head and neck cancer in homosexual men (men having sex with men) practicing oral-penile sex(). 
There are several limitations in our study. Although we have stratified our study by head and neck cancer subisites and by geographical regions, heterogeneity still persists across studies as it was based on literature reviews. Although the total number of patients included in meta-analysis was relatively large, however, the number of studies that could be combined to find out information about specific association was relatively small. This is one of the major limitations that could not be overcome by any statistical technique. Moreover, only fifteen studies out of sixty-six, used control subjects for the comparison of HPV-association. Misclassification of anatomical subsites of head and neck squamous cell carcinoma is of another concern. Analysis by anatomical subsites in the Asia Pacific showed that tonsils have the highest HPV prevalence in East Asia and Oceania. Where as, a high prevalence of HPV association was reported for "tongue cancer" $(6,73,77,80$, 81) in South Asia and South East Asia without separation of the oral tongue from the posterior third/base of tongue (C01). The latter is part of the oropharynx and, worldwide, has a higher prevalence of HPV-related HNSCC than the mobile tongue (97). Generally, infrequent association of HPV is noted with the mobile tongue (C02), floor of the mouth (C04), buccal mucosa (C03) and palate (C05) $(27,98)$. Those sites With this anatomical ambiguity, we considered tumors of the tongue as of oral cavity cancer, which may have resulted in overestimation of HPV association with the mouth (oral cavity), recording $38.91 \%$ (95\%Cl, 37.21 - 40.61). Such misclassification could also explain about the presence of heterogeneity in the meta-analysis that was performed on HPV -associated Oral cavity cancer. Further categorization of other anatomical subsites was also imprecise with terms like 'Oral cavity', 'Mandible, 'Maxilla', 'others’ or even ‘Unspecified/Unknown site’ (Table 1). Therefore, an appropriate site-specific classification of head and neck cancer is warranted. In future studies, we strongly recommend the systematic use of detailed ICD10 (International classification of Diseases- revision 10) codes for all studies of HNC to avoid misclassification.

Information about the age, sexual behaviour and habitual distributions were not properly addressed in most of the studies across the Asia Pacific. Therefore, it was not possible to assess the role of sexual behaviour in HPV-positive HNSCC or even the co-relation between the HPV-positive HNSCC and tobacco (smoking/smokeless), areca nut or alcohol consumption as its risk factors. However, few studies from the South Asia and 
East Asia have suggested a significantly higher association of HPV-associated HNSCC in smokers and betel quid chewers compared to non-smokers or non smokeless tobacco users. Another major confounding factor is the geographical location. HPV prevalence in OCC is considerably higher in Asia, especially, in South Asia, South East Asia and East Asia, compared to Europe, North America or even Oceania. Such association is opposite incase of HPV-associated OPC. Due to geographic heterogeneity, the present review should therefore be interpreted with caution. Although HPV- associated OPC is more commonly observed across the globe, our study has shown a lower prevalence of HPVassociated orophayrngeal cancer in South Asia compared to HPV-positive OCC. One of the major reasons could be misclassification of the anatomical sites. Moreover, biasness in sample collection, different types of different types of sampling and detection methods could be other confounding factors. Since most of the HNSCC cases in South Asia are observed in the oral cavity of the patient due to extensive use of tobacco both in smoking and smokeless forms, majority of these studies included in this review collected oral cavity samples. Only 2 studies out of 20, reported the prevalence of HPV -association with oropharyngeal cancer. Therefore, more studies are required to understand the true prevalence of HPV-associated OPC in South Asian populations.

Selection of the type of specimen is another important factor to be taken in account while determining the association of HPV. The tissue biopsy represents more appropriate feature of oral mucosae compared to exfoliated cytology or even saliva, and this includes basal layer cells where HPV could be present in latent state (). Transmission of the HPV is primarily through 'skin to skin' contact and integration of an oncogenic strain of the virus into the tissue of host genome is essential for cancer to supervene $(99,100)$. A large number of saliva samples from the general public, which would include exfoliated epithelial cells, have been screened across USA, and prevalence for carriage of high-risk HPV genotypes of 3.1\% was found (101). In interpreting the public health implications of this finding, it would be important to know how many individuals cleared or retained this infection, and the proportion of such individuals in whom integration of the virus might have occurred (102). 
Other limitations include variation in HPV DNA detection method and lack of standardized histo-pathological assessment. The method of detection of HPV may be an important source for heterogeneity across studies. The sensitivity and specificity of the method used to detect and type HPV is clearly critical in comparing studies due to the weak viral productivity in the upper aero-digestive tract mucosae. It is also important to remember that the techniques used also should be reproducible, subject to standardization, free from contamination and be economically viable. PCR assay could be the technique of choice as it is a sensitive, time-efficient, and requires minimal tissue, but is moderately expensive (103) and there is a risk of false positives. Inappropriate length of the consensus primer pair or over-amplification of the HPV DNA type-specific primers could be another reason that may result in excessive sensitivity with false positives from contamination (104): it is always important to ensure a clean and sterile environment while performing PCR. Further, recent studies have shown that combination of two sets of primers such as "PGMY/GP+" or "MY09/11" \& “GP5+/6+" in nested PCR is more efficient for detection of HPV in oropharyngeal cancer tissues, which may have very low viral load (105-107). More recently, the E6/E7 mRNA detection method has been defined as the gold-standard test to exemplify the oncogenic role of HPV in the tumour. However, the sensitivity of this test could also be hampered by the use of paraffin embedded tissue as nucleic acid degradation may take place during the fixation process. Although real time quantitative PCR (RT-qPCR) could be a better choice for HPV DNA detection due to its high-throughput analysis, it would still be very expensive compared to conventional PCR which remains the preferred method especially for use in resource-poor settings. Recently, a commercial “Di-gene 2” kit (Hybrid capture 2) has been promoted to screen large numbers of samples in a short time frame. This, however, is currently very expensive where 100 tests would cost approximately 2000 USD (www.Qiagen.com, accessed on 12 February, 2014). There are other HPV DNA detection methods available including ISH and p16 immunohstochemistry. Both ISH and p16 assays are highly sensitive but lack specificity. A recent study by Boy et al. showed 12\% HPV-positivity in oral squamous cell carcinoma with quantitative real time PCR, but zero with ISH on the same samples (108). 
Management protocols for HNC patients differ from person to person depending on anatomical location, age, medical conditions or/and tumour stage $(19,109,110)$. Recent reports indicate better survival and treatment outcomes for HPV-associated HNSCC patients compared to HPV-negative cancers (111-113). All these factors therefore need to be taken into account in treatment planning as de-intensifies therapy can be applied to the HPV-positive subset of HNC patients, reducing treatment related non-specific toxicity and health case costs. Although vaccine against HPV-associated cervical cancer has already been well introduced to school going girls, however, effectiveness of such vaccine is not well documented in other HPV derived cancers. Recently, Few countries, such as USA, Canada, Australia have recommended male vaccination. If this vaccine proves to be effective, a substantial amount of HPV-associated HNSCC could be prevented.

\section{Conclusion:}

In the past 30 years, there has been growing evidence suggesting a significant involvement of HPV in head and neck squamous cell carcinoma. This meta-analysis covers available data from the Asia Pacific as a whole. It covers a region of the world where tobacco-related HNSCC is a major concern, but suggests that HPV-related cancers are also significant. The prevalence of high risk HPVs appears similar to other countries, however, more number comprehensive studies are necessary on oropharyngeal cancer especially from South Asia, South East Asia and East Asia for better the understanding of HPV association with head and neck cancer in these particular regions. Further studies using the best techniques available with site-specific classification (preferably, use of ICD10 codes) and on larger \& better-defined populations with more appropriate control subjects \& tissues are clearly needed. It would also be of value to screen populations at risk for carriage and persistence of high-risk genotypes, especially in subjects with existing oral potentially malignant disorders. 


\section{Conflict of interest statement:}

The author(s) declare that they have no competing interests.

\section{Authors' contributions:}

MHS performed the initial literature searches and all authors agreed on selected papers. MHS also extracted data and prepared the meta-analyses, tables and diagrams. He wrote the first draft and agreed the final manuscript.

NM advised and contributed on molecular aspects and agreed the final manuscript.

NWJ contributed to data interpretation, manuscript revision and agreed the final manuscript.

\section{Acknowledgements:}

MHS is funded by Griffith University scholarships for international students.

\section{References:}

1. Syrjanen S. Human papillomavirus (HPV) in head and neck cancer. Journal of clinical virology : the official publication of the Pan American Society for Clinical Virology. 2005 Mar;32 Suppl 1:S59-66. PubMed PMID: 15753013. Epub 2005/03/09. eng.

2. Mehanna H, Paleri V, West CM, Nutting C. Head and neck cancer--Part 1: Epidemiology, presentation, and prevention. BMJ (Clinical research ed). 2010;341:c4684. PubMed PMID: 20855405. Epub 2010/09/22. eng.

3. Chan AT. Nasopharyngeal carcinoma. Annals of oncology : official journal of the European Society for Medical Oncology / ESMO. 2010 Oct;21 Suppl 7:vii308-12. PubMed PMID: 20943634. Epub 2010/10/15. eng.

4. Chou J, Lin YC, Kim J, You L, Xu Z, He B, et al. Nasopharyngeal carcinoma--review of the molecular mechanisms of tumorigenesis. Head \& neck. 2008 Jul;30(7):946-63. PubMed PMID: 18446839. Pubmed Central PMCID: PMC3046044. Epub 2008/05/01. eng.

5. Parkin DM, Bray F, Ferlay J, Pisani P. Global cancer statistics, 2002. CA: a cancer journal for clinicians. 2005 Mar-Apr;55(2):74-108. PubMed PMID: 15761078. Epub 2005/03/12. eng.

6. D'Costa J, Saranath D, Dedhia P, Sanghvi V, Mehta AR. Detection of HPV-16 genome in human oral cancers and potentially malignant lesions from India. Oral oncology. 1998 Sep;34(5):413-20. PubMed PMID: 9861351. Epub 1998/12/23. eng.

7. Parkin DM, Bray F. Chapter 2: The burden of HPV-related cancers. Vaccine. 2006 Aug 31;24 Suppl 3:S3/11-25. PubMed PMID: 16949997. Epub 2006/09/05. eng. 
8. Ryerson $A B$, Peters ES, Coughlin SS, Chen VW, Gillison ML, Reichman ME, et al. Burden of potentially human papillomavirus-associated cancers of the oropharynx and oral cavity in the US, 1998-2003. Cancer. 2008 Nov 15;113(10 Suppl):2901-9. PubMed PMID: 18980273. Epub 2008/11/05. eng.

9. Doobaree IU, Landis SH, Linklater KM, El-Hariry I, Moller H, Tyczynski J. Head and neck cancer in South East England between 1995-1999 and 2000-2004: An estimation of incidence and distribution by site, stage and histological type. Oral oncology. 2009 Sep;45(9):809-14. PubMed PMID: 19251472. Epub 2009/03/03. eng.

10. Hammarstedt $L$, Dahlstrand $H$, Lindquist $D$, Onelov L, Ryott $M$, Luo J, et al. The incidence of tonsillar cancer in Sweden is increasing. Acta oto-laryngologica. 2007 Sep;127(9):988-92. PubMed PMID: 17712680. Epub 2007/08/23. eng.

11. Ariyawardana A, Johnson NW. Trends of lip, oral cavity and oropharyngeal cancers in Australia 1982-2008: overall good news but with rising rates in the oropharynx. BMC cancer. 2013;13:333. PubMed PMID: 23829309. Pubmed Central PMCID: PMC3716721. Epub 2013/07/09. eng.

12. Herrero R, Castellsague X, Pawlita M, Lissowska J, Kee F, Balaram P, et al. Human papillomavirus and oral cancer: the International Agency for Research on Cancer multicenter study. Journal of the National Cancer Institute. 2003 Dec 3;95(23):1772-83. PubMed PMID: 14652239. Epub 2003/12/05. eng.

13. Ramqvist T, Dalianis T. An epidemic of oropharyngeal squamous cell carcinoma (OSCC) due to human papillomavirus (HPV) infection and aspects of treatment and prevention. Anticancer research. 2011 May;31(5):1515-9. PubMed PMID: 21617204. Epub 2011/05/28. eng.

14. Chang F, Syrjanen S, Kellokoski J, Syrjanen K. Human papillomavirus (HPV) infections and their associations with oral disease. Journal of oral pathology \& medicine : official publication of the International Association of Oral Pathologists and the American Academy of Oral Pathology. 1991 Aug;20(7):305-17. PubMed PMID: 1654422. Epub 1991/08/01. eng.

15. Jung WW, Chun T, Sul D, Hwang KW, Kang HS, Lee DJ, et al. Strategies against human papillomavirus infection and cervical cancer. Journal of microbiology (Seoul, Korea). 2004 Dec;42(4):255-66. PubMed PMID: 15650698. Epub 2005/01/15. eng.

16. Munoz N, Bosch FX, de Sanjose S, Herrero R, Castellsague X, Shah KV, et al. Epidemiologic classification of human papillomavirus types associated with cervical cancer. The New England journal of medicine. 2003 Feb 6;348(6):518-27. PubMed PMID: 12571259. Epub 2003/02/07. eng.

17. Syrjanen S. Human papillomavirus infections and oral tumors. Medical microbiology and immunology. 2003 Aug;192(3):123-8. PubMed PMID: 12920585. Epub 2003/08/16. eng.

18. Thorland EC, Myers SL, Gostout BS, Smith DI. Common fragile sites are preferential targets for HPV16 integrations in cervical tumors. Oncogene. 2003 Feb 27;22(8):1225-37. PubMed PMID: 12606949. Epub 2003/02/28. eng.

19. Marur S, D'Souza G, Westra WH, Forastiere AA. HPV-associated head and neck cancer: a virus-related cancer epidemic. The lancet oncology. 2010 Aug;11(8):781-9. PubMed PMID: 20451455. Epub 2010/05/11. eng.

20. Gillison ML, Koch WM, Capone RB, Spafford M, Westra WH, Wu L, et al. Evidence for a causal association between human papillomavirus and a subset of head and neck cancers. Journal of the National Cancer Institute. 2000 May 3;92(9):709-20. PubMed PMID: 10793107. Epub 2000/05/04. eng.

21. Ferlay J, Shin HR, Bray F, Forman D, Mathers C, Parkin DM. Estimates of worldwide burden of cancer in 2008: GLOBOCAN 2008. International journal of cancer Journal international du cancer. 2010 Dec 15;127(12):2893-917. PubMed PMID: 21351269. Epub 2011/02/26. eng. 
22. Walboomers JM, Jacobs MV, Manos MM, Bosch FX, Kummer JA, Shah KV, et al. Human papillomavirus is a necessary cause of invasive cervical cancer worldwide. The Journal of pathology. 1999 Sep;189(1):12-9. PubMed PMID: 10451482. Epub 1999/08/19. eng.

23. McKaig RG, Baric RS, Olshan AF. Human papillomavirus and head and neck cancer: epidemiology and molecular biology. Head \& neck. 1998 May;20(3):250-65. PubMed PMID: 9570632. Epub 1998/05/07. eng.

24. Gillison ML, Shah KV. Human papillomavirus-associated head and neck squamous cell carcinoma: mounting evidence for an etiologic role for human papillomavirus in a subset of head and neck cancers. Current opinion in oncology. 2001 May;13(3):183-8. PubMed PMID: 11307062. Epub 2001/04/18. eng.

25. Kreimer AR, Clifford GM, Boyle P, Franceschi S. Human papillomavirus types in head and neck squamous cell carcinomas worldwide: a systematic review. Cancer epidemiology, biomarkers \& prevention : a publication of the American Association for Cancer Research, cosponsored by the American Society of Preventive Oncology. 2005 Feb;14(2):467-75. PubMed PMID: 15734974. Epub 2005/03/01. eng.

26. Hammarstedt L, Lindquist D, Dahlstrand H, Romanitan M, Dahlgren LO, Joneberg J, et al. Human papillomavirus as a risk factor for the increase in incidence of tonsillar cancer. International journal of cancer Journal international du cancer. 2006 Dec 1;119(11):2620-3. PubMed PMID: 16991119. Epub 2006/09/23. eng.

27. Chaturvedi AK, Engels EA, Pfeiffer RM, Hernandez BY, Xiao W, Kim E, et al. Human papillomavirus and rising oropharyngeal cancer incidence in the United States. Journal of clinical oncology : official journal of the American Society of Clinical Oncology. 2011 Nov 10;29(32):4294-301. PubMed PMID: 21969503. Pubmed Central PMCID: PMC3221528. Epub 2011/10/05. eng.

28. Shiboski $\mathrm{CH}$, Schmidt BL, Jordan RC. Tongue and tonsil carcinoma: increasing trends in the U.S. population ages 20-44 years. Cancer. 2005 May 1;103(9):1843-9. PubMed PMID: 15772957. Epub 2005/03/18. eng.

29. Braakhuis BJ, Visser O, Leemans CR. Oral and oropharyngeal cancer in The Netherlands between 1989 and 2006: Increasing incidence, but not in young adults. Oral oncology. 2009 Sep;45(9):e85-9. PubMed PMID: 19457708. Epub 2009/05/22. eng.

30. Nasman A, Attner P, Hammarstedt L, Du J, Eriksson M, Giraud G, et al. Incidence of human papillomavirus (HPV) positive tonsillar carcinoma in Stockholm, Sweden: an epidemic of viral-induced carcinoma? International journal of cancer Journal international du cancer. 2009 Jul 15;125(2):362-6. PubMed PMID: 19330833. Epub 2009/03/31. eng.

31. Syrjanen S. HPV infections and tonsillar carcinoma. Journal of clinical pathology. 2004 May;57(5):449-55. PubMed PMID: 15113849. Pubmed Central PMCID: PMC1770289. Epub 2004/04/29. eng.

32. Palmer E, Newcombe RG, Green AC, Kelly C, Noel Gill O, Hall G, et al. Human papillomavirus infection is rare in nonmalignant tonsil tissue in the UK: implications for tonsil cancer precursor lesions. International journal of cancer Journal international du cancer. 2014 Nov 15;135(10):2437-43. PubMed PMID: 24723209. Epub 2014/04/12. eng.

33. Hong $A$, Lee CS, Jones $D$, Veillard $A$, Zhang $M$, Zhang $X$, et al. Rising prevalence of human papillomavirus related oropharyngeal cancer in Australia over the last two decades. Head \& neck. 2014 Dec 18. PubMed PMID: 25521312. Epub 2014/12/19. Eng.

34. Mehanna H, Beech T, Nicholson T, El-Hariry I, McConkey C, Paleri V, et al. Prevalence of human papillomavirus in oropharyngeal and nonoropharyngeal head and neck cancer-systematic review and meta-analysis of trends by time and region. Head \& neck. 2013 May;35(5):747-55. PubMed PMID: 22267298. Epub 2012/01/24. eng. 
35. Kumar RV, Kadkol SS, Daniel R, Shenoy AM, Shah KV. Human papillomavirus, p53 and cyclin D1 expression in oropharyngeal carcinoma. International journal of oral and maxillofacial surgery. 2003 Oct;32(5):539-43. PubMed PMID: 14759115. Epub 2004/02/05. eng.

36. Bahl A, Kumar P, Dar L, Mohanti BK, Sharma A, Thakar A, et al. Prevalence and trends of human papillomavirus in oropharyngeal cancer in a predominantly north Indian population. Head \& neck. 2013 Jun 1. PubMed PMID: 23729189. Epub 2013/06/05. Eng.

37. Paz IB, Cook N, Odom-Maryon T, Xie Y, Wilczynski SP. Human papillomavirus (HPV) in head and neck cancer. An association of HPV 16 with squamous cell carcinoma of Waldeyer's tonsillar ring. Cancer. 1997 Feb 1;79(3):595-604. PubMed PMID: 9028373. Epub 1997/02/01. eng.

38. Wilczynski SP, Lin BT, Xie Y, Paz IB. Detection of human papillomavirus DNA and oncoprotein overexpression are associated with distinct morphological patterns of tonsillar squamous cell carcinoma. The American journal of pathology. 1998 Jan;152(1):145-56. PubMed PMID: 9422532. Pubmed Central PMCID: PMC1858109. Epub 1998/01/09. eng.

39. Barnes L, Ferlito A, Altavilla G, MacMillan C, Rinaldo A, Doglioni C. Basaloid squamous cell carcinoma of the head and neck: clinicopathological features and differential diagnosis. The Annals of otology, rhinology, and laryngology. 1996 Jan;105(1):75-82. PubMed PMID: 8546432. Epub 1996/01/01. eng.

40. Andl T, Kahn T, Pfuhl A, Nicola T, Erber R, Conradt C, et al. Etiological involvement of oncogenic human papillomavirus in tonsillar squamous cell carcinomas lacking retinoblastoma cell cycle control. Cancer research. 1998 Jan 1;58(1):5-13. PubMed PMID: 9426048. Epub 1998/01/13. eng.

41. Benard VB, Johnson CJ, Thompson TD, Roland KB, Lai SM, Cokkinides V, et al. Examining the association between socioeconomic status and potential human papillomavirus-associated cancers. Cancer. 2008 Nov 15;113(10 Suppl):2910-8. PubMed PMID: 18980274. Epub 2008/11/05. eng.

42. Gillison ML, D'Souza G, Westra W, Sugar E, Xiao W, Begum S, et al. Distinct risk factor profiles for human papillomavirus type 16-positive and human papillomavirus type 16-negative head and neck cancers. Journal of the National Cancer Institute. 2008 Mar 19;100(6):407-20. PubMed PMID: 18334711. Epub 2008/03/13. eng.

43. Llewellyn CD, Johnson NW, Warnakulasuriya KA. Risk factors for squamous cell carcinoma of the oral cavity in young people--a comprehensive literature review. Oral oncology. 2001 Jul;37(5):401-18. PubMed PMID: 11377229. Epub 2001/05/30. eng.

44. Gillison ML. Human papillomavirus and prognosis of oropharyngeal squamous cell carcinoma: implications for clinical research in head and neck cancers. Journal of clinical oncology : official journal of the American Society of Clinical Oncology. 2006 Dec 20;24(36):5623-5. PubMed PMID: 17179099. Epub 2006/12/21. eng.

45. Klozar J, Kratochvil V, Salakova M, Smahelova J, Vesela E, Hamsikova E, et al. HPV status and regional metastasis in the prognosis of oral and oropharyngeal cancer. European archives of oto-rhino-laryngology : official journal of the European Federation of Oto-Rhino-Laryngological Societies (EUFOS) : affiliated with the German Society for Oto-Rhino-Laryngology - Head and Neck Surgery. 2008 Jul;265 Suppl 1:S75-82. PubMed PMID: 18094985. Epub 2007/12/21. eng.

46. Lindel K, Beer KT, Laissue J, Greiner RH, Aebersold DM. Human papillomavirus positive squamous cell carcinoma of the oropharynx: a radiosensitive subgroup of head and neck carcinoma. Cancer. 2001 Aug 15;92(4):805-13. PubMed PMID: 11550151. Epub 2001/09/11. eng. 
47. Maden C, Beckmann AM, Thomas DB, McKnight B, Sherman KJ, Ashley RL, et al. Human papillomaviruses, herpes simplex viruses, and the risk of oral cancer in men. American journal of epidemiology. 1992 May 15;135(10):1093-102. PubMed PMID: 1321561. Epub 1992/05/15. eng. 48. Schwartz SM, Daling JR, Doody DR, Wipf GC, Carter JJ, Madeleine MM, et al. Oral cancer risk in relation to sexual history and evidence of human papillomavirus infection. Journal of the National Cancer Institute. 1998 Nov 4;90(21):1626-36. PubMed PMID: 9811312. Epub 1998/11/12. eng.

49. D'Souza G, Agrawal Y, Halpern J, Bodison S, Gillison ML. Oral sexual behaviors associated with prevalent oral human papillomavirus infection. The Journal of infectious diseases. 2009 May 1;199(9):1263-9. PubMed PMID: 19320589. Epub 2009/03/27. eng.

50. Heck JE, Berthiller J, Vaccarella S, Winn DM, Smith EM, Shan'gina O, et al. Sexual behaviours and the risk of head and neck cancers: a pooled analysis in the International Head and Neck Cancer Epidemiology (INHANCE) consortium. International journal of epidemiology. 2010 Feb;39(1):166-81. PubMed PMID: 20022926. Pubmed Central PMCID: PMC2817092. Epub 2009/12/22. eng.

51. Rosenquist K, Wennerberg J, Schildt EB, Bladstrom A, Goran Hansson B, Andersson G. Oral status, oral infections and some lifestyle factors as risk factors for oral and oropharyngeal squamous cell carcinoma. A population-based case-control study in southern Sweden. Acta otolaryngologica. 2005 Dec;125(12):1327-36. PubMed PMID: 16303683. Epub 2005/11/24. eng.

52. D'Souza G, Kreimer AR, Viscidi R, Pawlita M, Fakhry C, Koch WM, et al. Case-control study of human papillomavirus and oropharyngeal cancer. The New England journal of medicine. 2007 May 10;356(19):1944-56. PubMed PMID: 17494927. Epub 2007/05/15. eng.

53. Rajkumar T, Sridhar H, Balaram P, Vaccarella S, Gajalakshmi V, Nandakumar A, et al. Oral cancer in Southern India: the influence of body size, diet, infections and sexual practices. European journal of cancer prevention : the official journal of the European Cancer Prevention Organisation (ECP). 2003 Apr;12(2):135-43. PubMed PMID: 12671537. Epub 2003/04/03. eng.

54. Smith EM, Ritchie JM, Summersgill KF, Klussmann JP, Lee JH, Wang D, et al. Age, sexual behavior and human papillomavirus infection in oral cavity and oropharyngeal cancers. International journal of cancer Journal international du cancer. 2004 Feb 20;108(5):766-72. PubMed PMID: 14696105. Epub 2003/12/30. eng.

55. Settle K, Posner MR, Schumaker LM, Tan M, Suntharalingam M, Goloubeva O, et al. Racial survival disparity in head and neck cancer results from low prevalence of human papillomavirus infection in black oropharyngeal cancer patients. Cancer prevention research (Philadelphia, Pa). 2009 Sep;2(9):776-81. PubMed PMID: 19641042. Epub 2009/07/31. eng.

56. zur Hausen H. Papillomaviruses and cancer: from basic studies to clinical application. Nature reviews Cancer. 2002 May;2(5):342-50. PubMed PMID: 12044010. Epub 2002/06/05. eng.

57. Crum CP, McLachlin CM, Tate JE, Mutter GL. Pathobiology of vulvar squamous neoplasia. Current opinion in obstetrics \& gynecology. 1997 Feb;9(1):63-9. PubMed PMID: 9090485. Epub 1997/02/01. eng.

58. Kayes O, Ahmed HU, Arya M, Minhas S. Molecular and genetic pathways in penile cancer. The lancet oncology. 2007 May;8(5):420-9. PubMed PMID: 17466899. Epub 2007/05/01. eng.

59. Munger K, Phelps WC, Bubb V, Howley PM, Schlegel R. The E6 and E7 genes of the human papillomavirus type 16 together are necessary and sufficient for transformation of primary human keratinocytes. Journal of virology. 1989 Oct;63(10):4417-21. PubMed PMID: 2476573. Pubmed Central PMCID: PMC251060. Epub 1989/10/01. eng. 
60. Werness BA, Levine AJ, Howley PM. Association of human papillomavirus types 16 and 18 E6 proteins with p53. Science (New York, NY). 1990 Apr 6;248(4951):76-9. PubMed PMID: 2157286. Epub 1990/04/06. eng.

61. Klingelhutz AJ, Foster SA, McDougall JK. Telomerase activation by the E6 gene product of human papillomavirus type 16. Nature. 1996 Mar 7;380(6569):79-82. PubMed PMID: 8598912. Epub 1996/03/07. eng.

62. van der Riet P, Nawroz H, Hruban RH, Corio R, Tokino K, Koch W, et al. Frequent loss of chromosome 9p21-22 early in head and neck cancer progression. Cancer research. 1994 Mar 1;54(5):1156-8. PubMed PMID: 8118798. Epub 1994/03/01. eng.

63. Dyson N, Howley PM, Munger K, Harlow E. The human papilloma virus-16 E7 oncoprotein is able to bind to the retinoblastoma gene product. Science (New York, NY). 1989 Feb 17;243(4893):934-7. PubMed PMID: 2537532. Epub 1989/02/17. eng.

64. Zhu L, van den Heuvel S, Helin K, Fattaey A, Ewen M, Livingston D, et al. Inhibition of cell proliferation by 107 , a relative of the retinoblastoma protein. Genes \& development. 1993 Jul;7(7A):1111-25. PubMed PMID: 8319904. Epub 1993/07/01. eng.

65. Claudio PP, Howard CM, Baldi A, De Luca A, Fu Y, Condorelli G, et al. p130/pRb2 has growth suppressive properties similar to yet distinctive from those of retinoblastoma family members pRb and p107. Cancer research. 1994 Nov 1;54(21):5556-60. PubMed PMID: 7923196. Epub 1994/11/01. eng.

66. Davies R, Hicks R, Crook T, Morris J, Vousden K. Human papillomavirus type 16 E7 associates with a histone $\mathrm{H} 1$ kinase and with p107 through sequences necessary for transformation. Journal of virology. 1993 May;67(5):2521-8. PubMed PMID: 8386265. Pubmed Central PMCID: PMC237571. Epub 1993/05/01. eng.

67. Newcombe RG. Two-sided confidence intervals for the single proportion: comparison of seven methods. Statistics in medicine. 1998 Apr 30;17(8):857-72. PubMed PMID: 9595616. Epub 1998/05/22. eng.

68. Higgins JP, Thompson SG. Quantifying heterogeneity in a meta-analysis. Statistics in medicine. 2002 Jun 15;21(11):1539-58. PubMed PMID: 12111919. Epub 2002/07/12. eng.

69. DerSimonian R, Laird N. Meta-analysis in clinical trials. Controlled clinical trials. 1986 Sep;7(3):177-88. PubMed PMID: 3802833. Epub 1986/09/01. eng.

70. Sterne JA, Sutton AJ, loannidis JP, Terrin N, Jones DR, Lau J, et al. Recommendations for examining and interpreting funnel plot asymmetry in meta-analyses of randomised controlled trials. BMJ (Clinical research ed). 2011;343:d4002. PubMed PMID: 21784880. Epub 2011/07/26. eng.

71. Balaram P, Nalinakumari KR, Abraham E, Balan A, Hareendran NK, Bernard HU, et al. Human papillomaviruses in 91 oral cancers from Indian betel quid chewers--high prevalence and multiplicity of infections. International journal of cancer Journal international du cancer. 1995 May 16;61(4):450-4. PubMed PMID: 7759149. Epub 1995/05/16. eng.

72. Pillai MR, Phanidhara A, Kesari AL, Nair P, Nair MK. Cellular manifestations of human papillomavirus infection in the oral mucosa. Journal of surgical oncology. 1999 May;71(1):10-5. PubMed PMID: 10362085. Epub 1999/06/11. eng.

73. Nagpal JK, Patnaik S, Das BR. Prevalence of high-risk human papilloma virus types and its association with $\mathrm{P} 53$ codon 72 polymorphism in tobacco addicted oral squamous cell carcinoma (OSCC) patients of Eastern India. International journal of cancer Journal international du cancer. 2002 Feb 10;97(5):649-53. PubMed PMID: 11807792. Epub 2002/01/25. eng.

74. Jacob SE, Sreevidya S, Chacko E, Pillai MR. Cellular manifestations of human papillomavirus infection in laryngeal tissues. Journal of surgical oncology. 2002 Mar;79(3):14250. PubMed PMID: 11870663. Epub 2002/03/01. eng. 
75. Jayasooriya PR KK, Terai M, Sivagnanam K, Siriwardana S, Tilakaratne M, Tagami J, Takagi M:. Human Papillomavirus in Oral Cancer from Sri Lanka: Prevalence and relationship with clinico-pathological parameters Oral Med Pathol. 2003;8:45-50. eng.

76. Koppikar P, deVilliers EM, Mulherkar R. Identification of human papillomaviruses in tumors of the oral cavity in an Indian community. International journal of cancer Journal international du cancer. 2005 Mar 1;113(6):946-50. PubMed PMID: 15514945. Epub 2004/10/30. eng.

77. Mitra S, Banerjee S, Misra C, Singh RK, Roy A, Sengupta A, et al. Interplay between human papilloma virus infection and p53 gene alterations in head and neck squamous cell carcinoma of an Indian patient population. Journal of clinical pathology. 2007 Sep;60(9):1040-7. PubMed PMID: 17079356. Pubmed Central PMCID: PMC1972436. Epub 2006/11/03. eng.

78. Castillo A, Koriyama C, Higashi M, Anwar M, Bukhari MH, Carrascal E, et al. Human papillomavirus in upper digestive tract tumors from three countries. World journal of gastroenterology : WJG. 2011 Dec 28;17(48):5295-304. PubMed PMID: 22219599. Pubmed Central PMCID: PMC3247694. Epub 2012/01/06. eng.

79. Kulkarni SS, Kulkarni SS, Vastrad PP, Kulkarni BB, Markande AR, Kadakol GS, et al. Prevalence and distribution of high risk human papillomavirus (HPV) Types 16 and 18 in Carcinoma of cervix, saliva of patients with oral squamous cell carcinoma and in the general population in Karnataka, India. Asian Pacific journal of cancer prevention : APJCP. 2011;12(3):645-8. PubMed PMID: 21627358. Epub 2011/06/02. eng.

80. Elango KJ, Suresh A, Erode EM, Subhadradevi L, Ravindran HK, Iyer SK, et al. Role of human papilloma virus in oral tongue squamous cell carcinoma. Asian Pacific journal of cancer prevention : APJCP. 2011;12(4):889-96. PubMed PMID: 21790221. Epub 2011/07/28. eng.

81. Jalouli J, Jalouli MM, Sapkota D, Ibrahim SO, Larsson PA, Sand L. Human papilloma virus, herpes simplex virus and epstein barr virus in oral squamous cell carcinoma from eight different countries. Anticancer research. 2012 Feb;32(2):571-80. PubMed PMID: 22287747. Epub 2012/01/31. eng.

82. Akhter M, Ali L, Hassan Z, Khan I. Association of human papilloma virus infection and oral squamous cell carcinoma in Bangladesh. Journal of health, population, and nutrition. 2013 Mar;31(1):65-9. PubMed PMID: 23617206. Pubmed Central PMCID: PMC3702360. Epub 2013/04/27. eng.

83. Termine N, Panzarella V, Falaschini S, Russo A, Matranga D, Lo Muzio L, et al. HPV in oral squamous cell carcinoma vs head and neck squamous cell carcinoma biopsies: a meta-analysis (1988-2007). Annals of oncology : official journal of the European Society for Medical Oncology / ESMO. 2008 Oct;19(10):1681-90. PubMed PMID: 18558666. Epub 2008/06/19. eng.

84. Shen J, Tate JE, Crum CP, Goodman ML. Prevalence of human papillomaviruses (HPV) in benign and malignant tumors of the upper respiratory tract. Modern pathology : an official journal of the United States and Canadian Academy of Pathology, Inc. 1996 Jan;9(1):15-20. PubMed PMID: 8821950. Epub 1996/01/01. eng.

85. Baumann JL, Cohen S, Evjen AN, Law JH, Vadivelu S, Attia A, et al. Human papillomavirus in early laryngeal carcinoma. The Laryngoscope. 2009 Aug;119(8):1531-7. PubMed PMID: 19489068. Epub 2009/06/03. eng.

86. Stephen JK, Chen KM, Shah V, Havard S, Lu M, Schweitzer VP, et al. Human papillomavirus outcomes in an access-to-care laryngeal cancer cohort. Otolaryngology--head and neck surgery : official journal of American Academy of Otolaryngology-Head and Neck Surgery. 2012 May;146(5):730-8. PubMed PMID: 22267491. Epub 2012/01/24. eng.

87. de Oliveira DE, Bacchi MM, Macarenco RS, Tagliarini JV, Cordeiro RC, Bacchi CE. Human papillomavirus and Epstein-Barr virus infection, p53 expression, and cellular proliferation in 
laryngeal carcinoma. American journal of clinical pathology. 2006 Aug;126(2):284-93. PubMed PMID: 16891205. Epub 2006/08/08. eng.

88. Torrente MC, Ampuero S, Abud M, Ojeda JM. Molecular detection and typing of human papillomavirus in laryngeal carcinoma specimens. Acta oto-laryngologica. 2005 Aug;125(8):88893. PubMed PMID: 16158538. Epub 2005/09/15. eng.

89. Salam MA, Rockett J, Morris A. General primer-mediated polymerase chain reaction for simultaneous detection and typing of human papillomavirus DNA in laryngeal squamous cell carcinomas. Clinical otolaryngology and allied sciences. 1995 Feb;20(1):84-8. PubMed PMID: 7788942. Epub 1995/02/01. eng.

90. Venuti A, Manni V, Morello R, De Marco F, Marzetti F, Marcante ML. Physical state and expression of human papillomavirus in laryngeal carcinoma and surrounding normal mucosa. Journal of medical virology. 2000 Apr;60(4):396-402. PubMed PMID: 10686022. Epub 2000/02/24. eng.

91. Snijders PJ, Scholes AG, Hart CA, Jones AS, Vaughan ED, Woolgar JA, et al. Prevalence of mucosotropic human papillomaviruses in squamous-cell carcinoma of the head and neck. International journal of cancer Journal international du cancer. 1996 May 16;66(4):464-9. PubMed PMID: 8635861. Epub 1996/05/16. eng.

92. Koskinen WJ, Brondbo K, Mellin Dahlstrand H, Luostarinen T, Hakulinen T, Leivo I, et al. Alcohol, smoking and human papillomavirus in laryngeal carcinoma: a Nordic prospective multicenter study. Journal of cancer research and clinical oncology. 2007 Sep;133(9):673-8. PubMed PMID: 17486368. Epub 2007/05/09. eng.

93. Hoffmann M, Scheunemann D, Fazel A, Gorogh T, Kahn T, Gottschlich S. Human papillomavirus and p53 polymorphism in codon 72 in head and neck squamous cell carcinoma. Oncology reports. 2009 Mar;21(3):809-14. PubMed PMID: 19212643. Epub 2009/02/13. eng.

94. Morshed K, Polz-Dacewicz M, Szymanski M, Smolen A. Usefulness and efficiency of formalin-fixed paraffin-embedded specimens from laryngeal squamous cell carcinoma in HPV detection by IHC and PCR/DEIA. Folia histochemica et cytobiologica / Polish Academy of Sciences, Polish Histochemical and Cytochemical Society. 2010 Sep 30;48(3):398-402. PubMed PMID: 21071345. Epub 2010/11/13. eng.

95. Licitra L, Zigon G, Gatta G, Sanchez MJ, Berrino F. Human papillomavirus in HNSCC: a European epidemiologic perspective. Hematology/oncology clinics of North America. 2008 Dec;22(6):1143-53, vii-viii. PubMed PMID: 19010264. Epub 2008/11/18. eng.

96. Hong AM, Dobbins TA, Lee CS, Jones D, Harnett GB, Armstrong BK, et al. Human papillomavirus predicts outcome in oropharyngeal cancer in patients treated primarily with surgery or radiation therapy. British journal of cancer. 2010 Nov 9;103(10):1510-7. PubMed PMID: 20959828. Pubmed Central PMCID: PMC2990586. Epub 2010/10/21. eng.

97. Dahlgren L, Dahlstrand HM, Lindquist D, Hogmo A, Bjornestal L, Lindholm J, et al. Human papillomavirus is more common in base of tongue than in mobile tongue cancer and is a favorable prognostic factor in base of tongue cancer patients. International journal of cancer Journal international du cancer. 2004 Dec 20;112(6):1015-9. PubMed PMID: 15386365. Epub 2004/09/24. eng.

98. Chaturvedi AK, Engels EA, Anderson WF, Gillison ML. Incidence trends for human papillomavirus-related and -unrelated oral squamous cell carcinomas in the United States. Journal of clinical oncology : official journal of the American Society of Clinical Oncology. 2008 Feb 1;26(4):612-9. PubMed PMID: 18235120. Epub 2008/02/01. eng.

99. zur Hausen H. Molecular pathogenesis of cancer of the cervix and its causation by specific human papillomavirus types. Current topics in microbiology and immunology. 1994;186:131-56. PubMed PMID: 8205839. Epub 1994/01/01. eng. 
100. Kadaja $\mathrm{M}$, Isok-Paas $\mathrm{H}$, Laos $\mathrm{T}$, Ustav $\mathrm{E}$, Ustav $\mathrm{M}$. Mechanism of genomic instability in cells infected with the high-risk human papillomaviruses. PLoS pathogens. 2009 Apr;5(4):e1000397. PubMed PMID: 19390600. Pubmed Central PMCID: PMC2666264. Epub 2009/04/25. eng.

101. Sanders AE, Slade GD, Patton LL. National prevalence of oral HPV infection and related risk factors in the U.S. adult population. Oral diseases. 2012 Jul;18(5):430-41. PubMed PMID: 22251072. Epub 2012/01/19. eng.

102. Prabhu SR, Wilson D, Johnson NW. Re: national prevalence of oral HPV infection and related risk factors in the U.S. adult population. Oral diseases. 2013 Jan;19(1):107-8. PubMed PMID: 22748114. Epub 2012/07/04. eng.

103. Pannone G, Santoro A, Papagerakis S, Lo Muzio L, De Rosa G, Bufo P. The role of human papillomavirus in the pathogenesis of head \& neck squamous cell carcinoma: an overview. Infectious agents and cancer. 2011;6:4. PubMed PMID: 21447181. Pubmed Central PMCID: PMC3072321. Epub 2011/03/31. eng.

104. Frank TS, Svoboda-Newman SM, Hsi ED. Comparison of methods for extracting DNA from formalin-fixed paraffin sections for nonisotopic PCR. Diagnostic molecular pathology : the American journal of surgical pathology, part B. 1996 Sep;5(3):220-4. PubMed PMID: 8866237. Epub 1996/09/01. eng.

105. Fuessel Haws AL, He Q, Rady PL, Zhang L, Grady J, Hughes TK, et al. Nested PCR with the PGMY09/11 and GP5(+)/6(+) primer sets improves detection of HPV DNA in cervical samples. Journal of virological methods. 2004 Dec 1;122(1):87-93. PubMed PMID: 15488625. Epub 2004/10/19. eng.

106. Winder DM, Ball SL, Vaughan K, Hanna N, Woo YL, Franzer JT, et al. Sensitive HPV detection in oropharyngeal cancers. BMC cancer. 2009;9:440. PubMed PMID: 20003490. Pubmed Central PMCID: PMC2803197. Epub 2009/12/17. eng.

107. Karlsen F, Kalantari M, Jenkins A, Pettersen E, Kristensen G, Holm R, et al. Use of multiple PCR primer sets for optimal detection of human papillomavirus. Journal of clinical microbiology. 1996 Sep;34(9):2095-100. PubMed PMID: 8862564. Pubmed Central PMCID: PMC229196. Epub 1996/09/01. eng.

108. Boy S, Van Rensburg EJ, Engelbrecht S, Dreyer L, van Heerden M, van Heerden W. HPV detection in primary intra-oral squamous cell carcinomas--commensal, aetiological agent or contamination? Journal of oral pathology \& medicine : official publication of the International Association of Oral Pathologists and the American Academy of Oral Pathology. 2006 Feb;35(2):86-90. PubMed PMID: 16430738. Epub 2006/01/25. eng.

109. Ang KK, Harris J, Wheeler R, Weber R, Rosenthal DI, Nguyen-Tan PF, et al. Human papillomavirus and survival of patients with oropharyngeal cancer. The New England journal of medicine. 2010 Jul 1;363(1):24-35. PubMed PMID: 20530316. Pubmed Central PMCID: PMC2943767. Epub 2010/06/10. eng.

110. Mellin H, Friesland S, Lewensohn R, Dalianis T, Munck-Wikland E. Human papillomavirus (HPV) DNA in tonsillar cancer: clinical correlates, risk of relapse, and survival. International journal of cancer Journal international du cancer. 2000 May 20;89(3):300-4. PubMed PMID: 10861508. Epub 2000/06/22. eng.

111. Marur S, Forastiere AA. Head and neck cancer: changing epidemiology, diagnosis, and treatment. Mayo Clinic proceedings. 2008 Apr;83(4):489-501. PubMed PMID: 18380996. Epub 2008/04/03. eng.

112. Smeets SJ, Brakenhoff RH, Ylstra B, van Wieringen WN, van de Wiel MA, Leemans CR, et al. Genetic classification of oral and oropharyngeal carcinomas identifies subgroups with a 
different prognosis. Cellular oncology : the official journal of the International Society for Cellular Oncology. 2009;31(4):291-300. PubMed PMID: 19633365. Epub 2009/07/28. eng.

113. Vidal L, Gillison ML. Human papillomavirus in HNSCC: recognition of a distinct disease type. Hematology/oncology clinics of North America. 2008 Dec;22(6):1125-42, vii. PubMed PMID: 19010263. Epub 2008/11/18. eng.

\section{Figure legends:}

Figure 1: A cartoon of Human papillomavirus type 16-genome organization.

This HPV16 genome is a double stranded circular DNA containing approximately 8000 base pairs with 3 regions: (1) early gene region containing open reading frames (ORF) for $E 1, E 2, E 4, E 5, E 6 \& E 7$ genes that are responsible for trans-activation, transcription, replication and viral adaptation. E6 \& E7 genes are viral oncogenes that contribute to carcinogenesis. (2) Late gene region encodes capsid proteins L1 and L2 that are responsible for viral DNA packaging and maturation and (3) one non-coding or long control region (LCR) which contains sequences for controlling viral transcription and replication. 


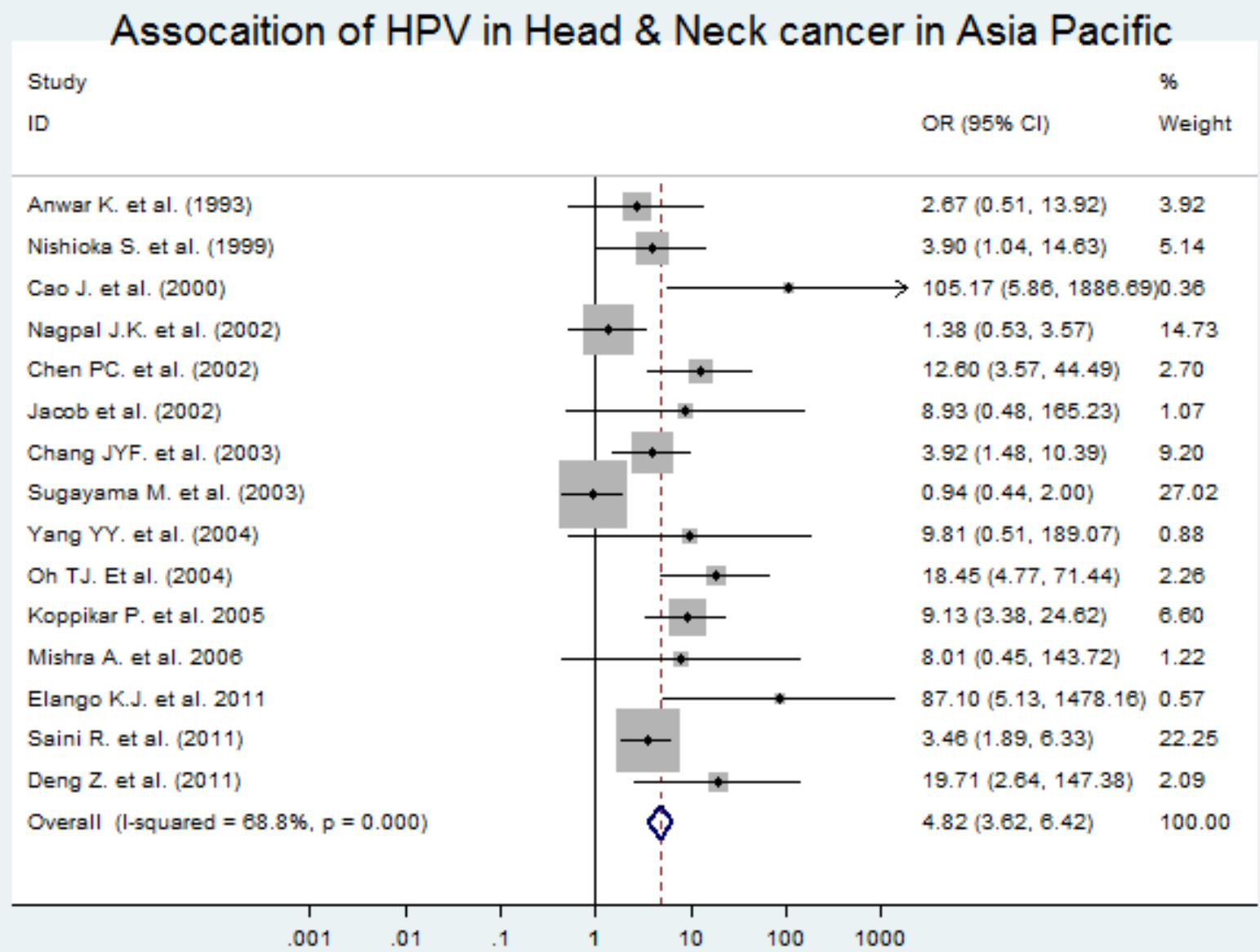

Association of HPV in Oral Cavity cancer in Asia Pacific Study

ID

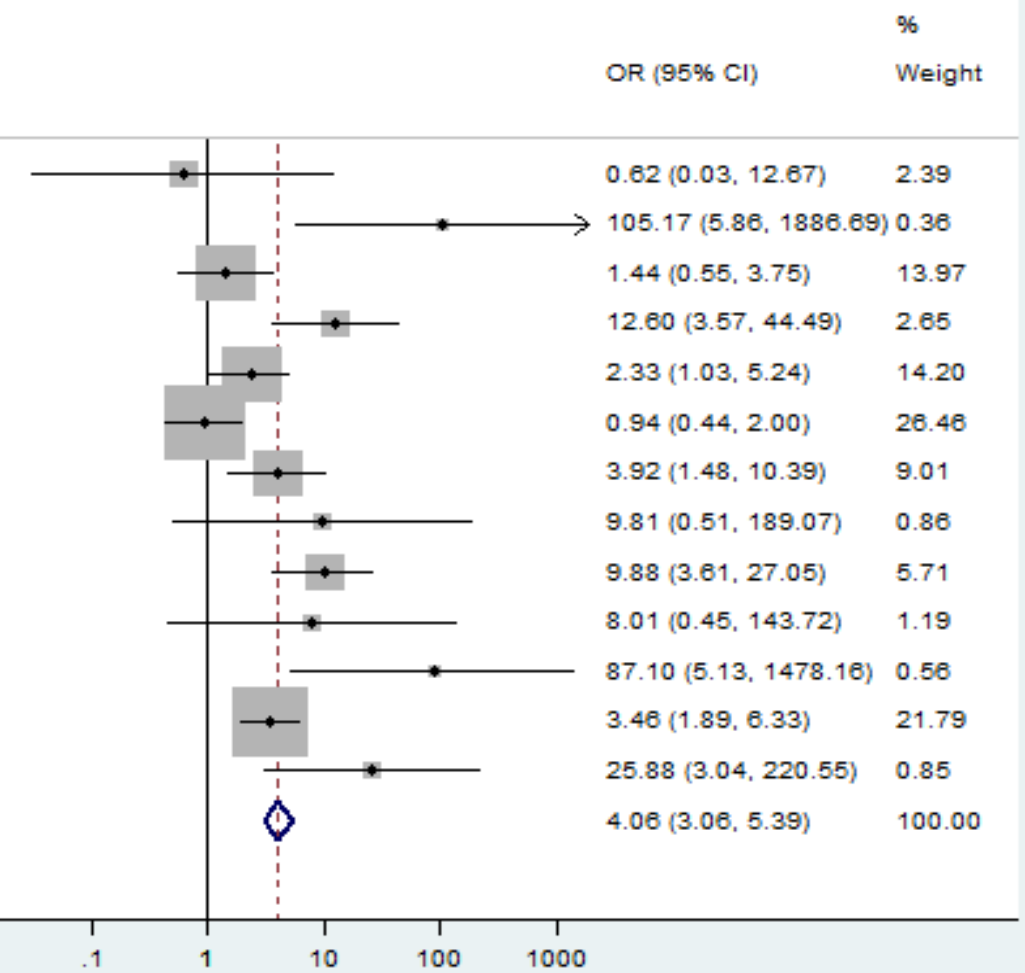




\section{Association HPV with Oro-pharynx in Asia Pacific}

Study

$\%$

ID

OR $(95 \% \mathrm{Cl})$

Weight

Nishioka S. et al. (1999)

Koppikar P. et al. 2005

Deng Z. et al. (2011)

Oh TJ. Et al. (2004)

Overall (l-squared $=0.0 \%, p=0.644)$

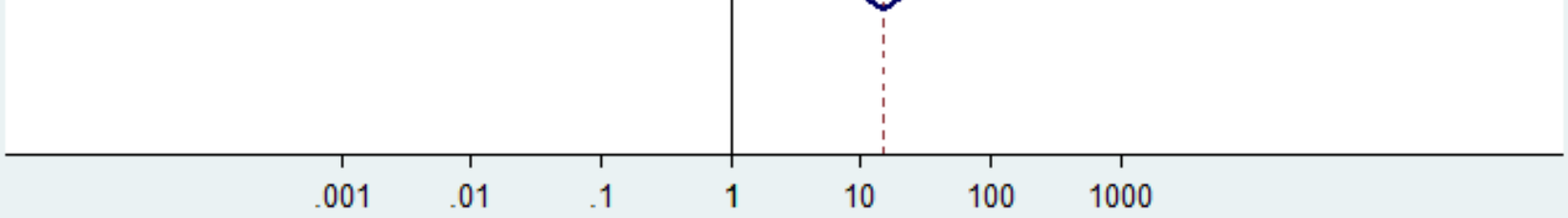

\section{Association of HPV in Laryngeal cancer in Asia Pacific}

Study

ID

Nishioka S. et al. (1999)

Jacob et al. (2002)

Deng Z. et al. (2011)

Anwar K. et al. (1993)

Overall $(l$-squared $=0.0 \%, p=0.553)$
OR $(95 \% \mathrm{Cl})$

$\%$

Weight

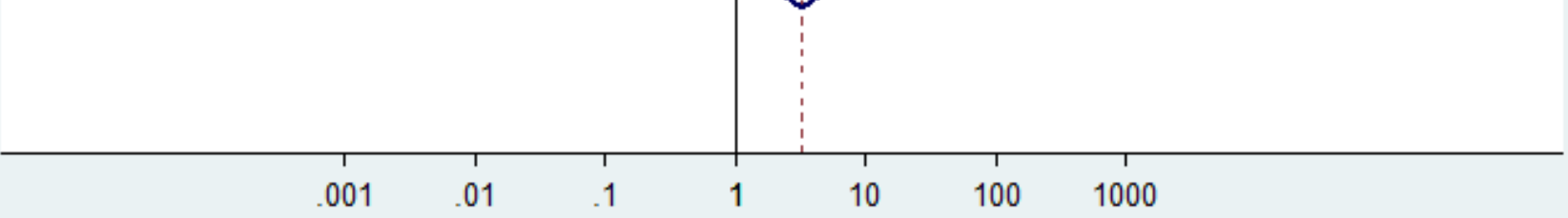

